
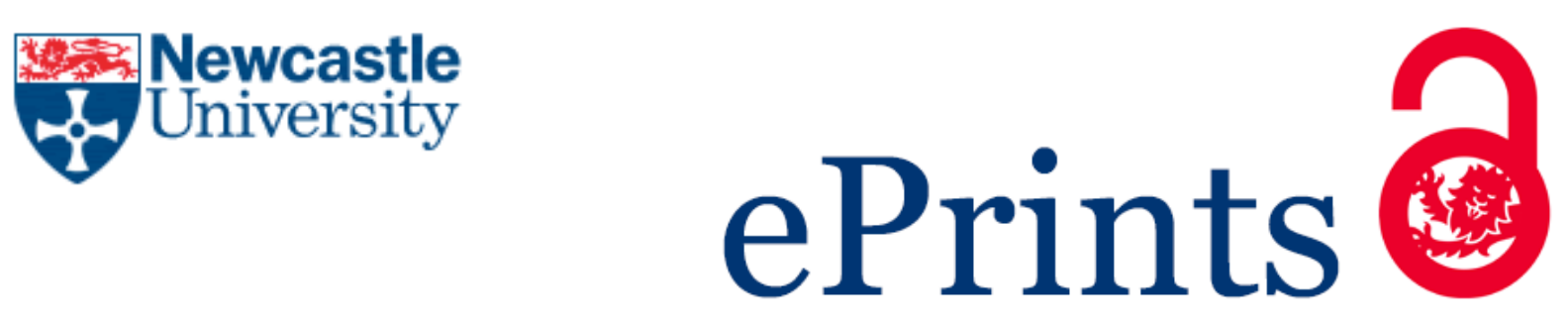

\author{
Haider A, Ibrahim M, Bassil BS, Carey AM, Viet AN, Xing XL, Ayass WW, \\ Minambres JF, Liu RJ, Zhang GJ, Keita B, Mereacre V, Powell AK, Balinski K, \\ N'Diaye AT, Kupper K, Chen HY, Stimming U, Kortz U. \\ Mixed-Valent $\mathrm{Mn}_{16}$-Containing Heteropolyanions: Tuning of Oxidation State \\ and Associated Physicochemical Properties. \\ Inorganic Chemistry 2016, 55(6), 2755-2764.
}

\title{
Copyright:
}

This document is the Accepted Manuscript version of a Published Work that appeared in final form in Inorganic Chemistry, copyright (CAmerican Chemical Society after peer review and technical editing by the publisher. To access the final edited and published work see http://pubs.acs.org/page/policy/articlesonrequest/index.html

DOI link to article:

http://dx.doi.org/10.1021/acs.inorgchem.5b02503

Date deposited:

$05 / 05 / 2016$

Embargo release date:

02 March 2017

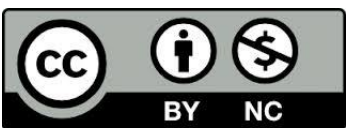

This work is licensed under a Creative Commons Attribution-NonCommercial 3.0 Unported License 


\section{Mixed-Valent $\mathrm{Mn}_{16}$-Containing Heteropolyanions:}

\section{Oxidation State Tuning and Resulting Physicochemical}

\section{Properties}

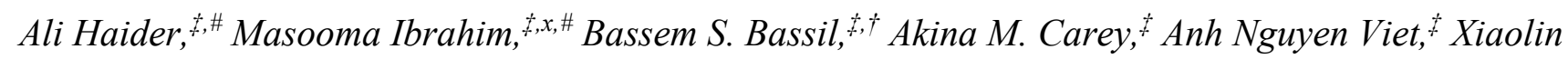

Xing, ${ }^{\ddagger}$ Wassim W. Ayass, ${ }^{+}$Juan F. Miñambres, ${ }^{\ddagger}$ Rongji Liu,${ }^{\ddagger}$ Guangjin Zhang, ${ }^{\ddagger}$ Bineta Keita, ${ }^{\mathbf{v}+}$ Valeriu Mereacre, ${ }^{\ominus}$ Annie K. Powell, ${ }^{\diamond, \bullet}$ Kamil Balinski, ${ }^{\bullet}$ Alpha T. N'Diaye, ${ }^{\circ}$ Karsten Küpper, ${ }^{\bullet}$ Han-Yi Chen, ${ }^{\natural, \Delta}$ Ulrich Stimming, ${ }^{\|, \Delta,}$ and Ulrich Kortz, ${ }^{*,+}$

$\ddagger$ Department of Life Sciences and Chemistry, Jacobs University, P.O. Box 750 561, 28725 Bremen, Germany.

$\dagger$ Department of Chemistry, Faculty of Sciences, University of Balamand, P.O. Box 100, Tripoli, Lebanon.

\#Key Laboratory of Green Process and Engineering, Institute of Process Engineering, Chinese Academy of Sciences, 100190, Beijing, China.

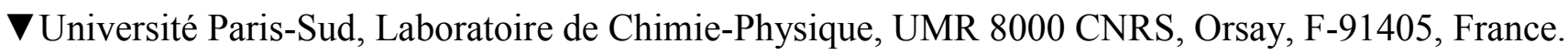

$\diamond$ Institute of Nanotechnology, Karlsruhe Institute of Technology (KIT), Hermann-von-Helmholtz Platz 1, 76344 Eggenstein-Leopoldshafen, Germany.

-Institute of Inorganic Chemistry, Karlsruhe Institute of Technology (KIT), Engesserstrasse 15, 76131 Karlsruhe, Germany. 
- Department of Physics and Center of Physics and Chemistry of New Materials, Osnabrück University, D-49069 Osnabrück, Germany.

oLawrence Berkeley National Laboratory, Berkeley, California 94720, USA.

ITUM CREATE, 1 CREATE Way, \#10-02 CREATE Tower, 138602 Singapore.

$\Delta$ Department of Chemistry, Technische Universität München, Lichtenbergstraße 4, 85748 Garching, Germany.

\School of Chemistry, Bedson Building, Newcastle University, Newcastle upon Tyne NE1 7RU, United Kingdom.

KEYWORDS: Polyoxometalates • Magnetism • Electrochemistry • Catalysis • Lithium-ion batteries 
ABSTRACT: The two 16-manganese-containing, Keggin-based 36-tungsto-4-silicates

$\left[\mathrm{Mn}^{\mathrm{III}}{ }_{10} \mathrm{Mn}_{6}{ }_{6} \mathrm{O}_{6}(\mathrm{OH})_{6}\left(\mathrm{PO}_{4}\right)_{4}\left(A-\alpha-\mathrm{SiW}_{9} \mathrm{O}_{34}\right)_{4}\right]^{28-}(\mathbf{1})$ and $\left[\mathrm{Mn}_{4}{ }_{4} \mathrm{Mn}_{12}{ }_{12}(\mathrm{OH})_{12}\left(\mathrm{PO}_{4}\right)_{4}\left(A-\alpha-\mathrm{SiW}_{9} \mathrm{O}_{34}\right)_{4}\right]^{28-}$

have been prepared by reaction of the trilacunary Keggin precursor $\left[A-\alpha-\mathrm{SiW}_{9} \mathrm{O}_{34}\right]^{10-}$ with either $\mathrm{Mn}\left(\mathrm{OOCCH}_{3}\right)_{3} \cdot 2 \mathrm{H}_{2} \mathrm{O}$ (for 1) or $\mathrm{MnCl}_{2} \cdot 4 \mathrm{H}_{2} \mathrm{O}$ (for 2), in aqueous phosphate solution at pH 9. Polyanions 1 and 2 comprise mixed-valent, cationic $\left\{\mathrm{Mn}^{\mathrm{III}}{ }_{10} \mathrm{Mn}_{6}{ }_{6} \mathrm{O}_{6}(\mathrm{OH})_{6}\right\}^{24+}$ and $\left\{\mathrm{Mn}^{\mathrm{III}}{ }_{4} \mathrm{Mn}_{12}^{\mathrm{II}}(\mathrm{OH})_{12}\right\}^{24+}$ cores, respectively, encapsulated by four phosphate groups and four $\left\{\mathrm{SiW}_{9}\right\}$ units in a tetrahedral fashion. Both polyanions were structurally and compositionally characterized by single-crystal XRD, IR, thermogravimetric analysis, and X-ray absorption spectroscopy. Furthermore, studies were performed probing the magnetic, electrochemical, oxidation catalytic, and Li-ion battery performance of 1 and 2.

\section{INTRODUCTION}

Condensation reactions of simple oxoanions of early transition metals in high oxidation states (e.g. $\mathrm{V}^{\mathrm{V}}, \mathrm{Mo}^{\mathrm{VI}}, \mathrm{W}^{\mathrm{VI}}$ ) in acidic, aqueous medium give rise to the formation of polynuclear structures known as polyoxometalates (POMs). ${ }^{1}$ In this process many factors such as $\mathrm{pH}$, temperature, concentration and ratio of reagents, and counter cations are crucial. Such phenomenon leads to a large number of novel POM structures with a vast variety in terms of shape, size, and composition, leading to interesting combinations of physiochemical properties with potential applications in areas ranging from heterogeneous and homogeneous catalysis to biomedical sciences. ${ }^{2}$ Recently, POMs have been reported as promising electrode materials for energy storage applications such as lithium-ion batteries (LIBs), sodium-ion batteries, and supercapacitors. ${ }^{3}$ Removal of one or more $\mathrm{MO}_{6}$ octahedra from plenary structures such as the Keggin ion (e.g. $\left[\mathrm{PW}_{12} \mathrm{O}_{40}\right]^{3-}$ ) or the Wells-Dawson ion (e.g. $\left[\mathrm{P}_{2} \mathrm{~W}_{18} \mathrm{O}_{62}\right]^{6-}$ ) results in so-called lacunary (vacant) derivatives (e.g. monolacunary $\left[\mathrm{PW}_{11} \mathrm{O}_{39}\right]^{7-}$, trilacunary $\left[\mathrm{P}_{2} \mathrm{~W}_{15} \mathrm{O}_{56}\right]^{12-}$ ), which can be considered as inorganic multidentate ligands, allowing for stabilization of most $d$ - and $f$-block metal ions. ${ }^{1,2}$

First row transition metal-containing heteropolytungstates are probably the largest subclass of POMs due to their structural, electronic, redox, magnetic, optical, and catalytic properties, having 
resulted in numerous studies on such compounds in many different areas of science. ${ }^{2 c, 4}$ POMs can be synthesized using conventional, 'open-beaker' conditions or by hydrothermal methods, with the latter frequently leading to extended POM-based solid-state networks, rather than discrete molecular polyanions. ${ }^{4}$

In particular, the class of manganese-containing heteropolytungstates is well-established and comprises many members. The number of incorporated manganese centers within these POMs ranges from one to 40, including some mixed-valent species (mostly common oxidation states II, III or IV). Some prominent examples include $\left\{\mathrm{Mn}^{\mathrm{II}} \mathrm{P}_{2} \mathrm{~W}_{17}\right\},{ }^{5 \mathrm{a}}\left\{\mathrm{Mn}^{\mathrm{II}} / \mathrm{Mn}^{\mathrm{III}} / \mathrm{Mn}^{\mathrm{IV}} \mathrm{AlW}_{11}\right\},{ }^{5 \mathrm{~b}}$ $\left\{\mathrm{Mn}^{\mathrm{II}}\left(\mathrm{SiW}_{10}\right)_{2}\right\},^{5 \mathrm{c}}\left\{\mathrm{Mn}^{\mathrm{II}}\left(\mathrm{PW}_{7}\right)_{2}\right\},^{5 \mathrm{~d}}\left\{\mathrm{Mn}^{\mathrm{III}}\left(\mathrm{SiW}_{9}\right)_{2}\right\},{ }^{5 \mathrm{e}} \quad\left\{\mathrm{Mn}_{2}^{\mathrm{III}} \mathrm{SiW}_{10}\right\},{ }^{6 \mathrm{a}} \quad\left\{\mathrm{Mn}_{2} \mathrm{As}_{2} \mathrm{~W}_{19}\right\},{ }^{6 \mathrm{~b}}$ $\left\{\mathrm{Mn}_{2} \mathrm{~W}_{5}\left(\mathrm{P}_{2} \mathrm{~W}_{12}\right)_{3}\right\},{ }^{6 \mathrm{c}}\left\{\mathrm{Mn}_{2}{ }_{2}\left(\mathrm{PW}_{9}\right)_{2}\right\},{ }^{6 \mathrm{~d}}\left\{\mathrm{Mn}^{\mathrm{II}} \mathrm{Mn}^{\mathrm{III}} \mathrm{SiW}_{10}\right\},{ }^{6 \mathrm{e}}\left\{\mathrm{Mn}_{2} \mathrm{II}_{2} \mathrm{~W}_{17}\right\},{ }^{6 \mathrm{f}}\left\{\mathrm{Mn}_{2}\left(\mathrm{SiW}_{8}\right)_{2}\right\},{ }^{6 \mathrm{~g}}$ $\left\{\mathrm{Mn}_{3} \mathrm{SiW}_{9}\right\},{ }^{7 \mathrm{a}, \mathrm{g}}\left\{\mathrm{Mn}_{3}{ }_{3}\left(\mathrm{SiW}_{11}\right)_{3}\right\},{ }^{7 \mathrm{~b}}\left\{\mathrm{Mn}_{3}{ }_{3}\left(\mathrm{AsW}_{9}\right)_{2}\right\},{ }^{7 \mathrm{c}}\left\{\mathrm{Mn}^{\mathrm{II}} \mathrm{Mn}_{2} \mathrm{III}_{2} \mathrm{SiW}_{9}\right\},{ }^{7 \mathrm{~d}} \quad\left\{\mathrm{Mn}_{3}^{\mathrm{III}}\left(\mathrm{PW}_{9}\right)_{2}\right\},{ }^{7 \mathrm{e}}$ $\left\{\mathrm{Mn}_{3}{ }_{3} \mathrm{SiW}_{9}\right\},{ }^{7 \mathrm{f}, \mathrm{g}} \quad\left\{\mathrm{Mn}_{4}{ }_{4}\left(\mathrm{PW}_{9}\right)_{2}\right\},{ }^{8 \mathrm{a}}\left\{\mathrm{Mn}_{4}^{\mathrm{II}}\left(\mathrm{P}_{2} \mathrm{~W}_{15}\right)_{2}\right\},{ }^{8 \mathrm{~b}}\left\{\mathrm{Mn}_{3}^{\mathrm{II}} \mathrm{Mn}^{\mathrm{III}} / \mathrm{Mn}^{\mathrm{II}} \mathrm{Mn}^{\mathrm{III}}{ }_{3}\left(\mathrm{PW}_{9}\right)_{2}\right\},{ }^{8 \mathrm{c}}$ $\left\{\mathrm{Mn}_{4}{ }_{4}^{\mathrm{II}}\left(\mathrm{As}_{2} \mathrm{~W}_{15}\right)_{2}\right\},{ }^{8 \mathrm{~d}}\left\{\mathrm{Mn}_{4}{ }_{4}\left(\mathrm{XW}_{9}\right)_{2}\right\}(\mathrm{X}=\mathrm{Si}, \mathrm{Ge}),{ }^{8 \mathrm{e}, \mathrm{f}}\left\{\mathrm{Mn}_{4}{ }_{4}\left(\mathrm{SiW}_{10}\right)_{2}\right\},{ }^{8 \mathrm{~g}}\left\{\mathrm{Mn}_{3}^{\mathrm{III}} \mathrm{Mn}^{\mathrm{IV}} \mathrm{P}_{2} \mathrm{~W}_{15}\right\},^{8 \mathrm{~h}}$ $\left\{\mathrm{Mn}_{4}{ }_{4} \mathrm{P}_{8} \mathrm{~W}_{48}\right\},^{8 \mathrm{i}} \quad\left\{\mathrm{Mn}_{2}{ }_{2} \mathrm{Mn}^{\mathrm{III}}{ }_{2}\left(\mathrm{P}_{2} \mathrm{~W}_{15}\right)_{2}\right\},{ }^{8 \mathrm{j}} \quad\left\{\mathrm{Mn}_{3}^{\mathrm{III}} \mathrm{Mn}^{\mathrm{IV}} \mathrm{SiW}_{9}\right\},{ }^{7 \mathrm{~g}, 8 \mathrm{k}} \quad\left\{\mathrm{Mn}_{5}^{\mathrm{III}}{ }_{5}\left(\mathrm{SiW}_{9}\right)_{2}\right\},{ }^{9}$ $\left\{\mathrm{Mn}_{6}{ }_{6}\left(\mathrm{PW}_{9}\right)_{2}\left(\mathrm{PW}_{6}\right)\right\},{ }^{10 \mathrm{a}}\left\{\mathrm{Mn}_{2} \mathrm{Mn}^{\mathrm{II}}{ }_{4}\left(\mathrm{XW}_{9}\right)_{2}\right\} \quad(\mathrm{X}=\mathrm{Si}, \mathrm{Ge}),{ }^{10 \mathrm{~b}} \quad\left\{\mathrm{Mn}_{6}{ }_{6}\left(\mathrm{GeW}_{10}\right)_{3}\right\},{ }^{10 \mathrm{c}}$ $\left\{\mathrm{Mn}_{6}{ }_{6} \mathrm{GeW}_{6}\left(\mathrm{GeW}_{9}\right)_{2}\right\},{ }^{10 \mathrm{~d}}\left\{\mathrm{Mn}_{4}{ }_{4} \mathrm{Mn}_{2}{ }_{2}\left(\mathrm{SiW}_{8}\right)\left(\mathrm{SiW}_{9}\right)\left(\mathrm{SiW}_{10}\right)\right\},{ }^{10 \mathrm{e}} \quad\left\{\mathrm{Mn}_{3} \mathrm{Mn}_{3} \mathrm{MII}_{3}\left(\mathrm{SiW}_{10}\right)_{3}\right\},{ }^{10 \mathrm{f}}$ $\left\{\mathrm{Mn}_{7}^{\mathrm{II}}\left(\mathrm{XW}_{9}\right)_{2}\left(\mathrm{XW}_{8}\right)_{2}\right\}(\mathrm{X}=\mathrm{Ge}, \mathrm{Si}),{ }^{11 \mathrm{a}, \mathrm{b}}\left\{\mathrm{Mn}_{6}^{\mathrm{III}}{ }_{6} \mathrm{Mn}^{\mathrm{IV}}\left(\mathrm{P}_{2} \mathrm{~W}_{15}\right)_{2}\right\},{ }^{11 \mathrm{c}}\left\{\mathrm{Mn}_{7}^{\mathrm{II}}\left(\mathrm{Si}_{2} \mathrm{~W}_{8}\right)_{2}\left(\mathrm{Si}_{2} \mathrm{~W}_{10}\right)_{2}\right\},{ }^{11 \mathrm{~d}}$ $\left\{\mathrm{Mn}_{8}{ }_{8} \mathrm{P}_{8} \mathrm{~W}_{48}\right\},{ }^{12 \mathrm{a}}\left\{\mathrm{Mn}_{8}{ }^{\mathrm{II}}\left(\mathrm{GeW}_{10}\right)_{3}\right\},{ }^{12 \mathrm{~b}} \quad\left\{\mathrm{Mn}_{10}{ }_{10}\left(\mathrm{SiW}_{9}\right)_{4}\right\},{ }^{11 \mathrm{~d}} \quad\left\{\mathrm{Mn}_{4}{ }_{4} \mathrm{Mn}^{\mathrm{III}}{ }_{6}\left(\mathrm{SiW}_{9}\right)_{2}\left(\mathrm{SiW}_{6}\right)_{2}\right\},{ }^{13}$ $\left\{\mathrm{Mn}_{4}{ }_{4} \mathrm{Mn}^{\mathrm{III}}{ }_{6} \mathrm{Mn}^{\mathrm{IV}}{ }_{2}\left(\mathrm{SiW}_{6}\right)_{2}\right\},{ }^{14}\left\{\mathrm{Mn}^{\mathrm{II}} \mathrm{Mn}^{\mathrm{III}}{ }_{13}\left(\mathrm{PW}_{9}\right)_{4}\right\},{ }^{15 \mathrm{a}}\left\{\mathrm{Mn}_{6}^{\mathrm{III}} \mathrm{Mn}^{\mathrm{IV}}{ }_{8} \mathrm{~W}_{48}\right\},{ }^{15 \mathrm{~b}}\left\{\mathrm{Mn}_{19}^{\mathrm{II}}\left(\mathrm{SiW}_{10}\right)_{6}\right\},{ }^{16}$ $\left\{\mathrm{Mn}_{40}\left(\mathrm{P}_{8} \mathrm{~W}_{48}\right)\left(\mathrm{P}_{2} \mathrm{~W}_{14}\right)_{4}\left(\mathrm{P}_{2} \mathrm{~W}_{15}\right)_{8}\right\} .{ }^{17}$ Moreover, other mixed-metal POMs containing manganese together with other $3 \mathrm{~d}$ or $4 \mathrm{f}$ metal ions are also known. ${ }^{18}$

Recently, Kortz and Bonchio have shown that the acetate-capped, mixed-valence tetramanganese-containing 9-tungstosilicate $\left[\mathrm{Mn}^{\mathrm{III}}{ }_{3} \mathrm{Mn}^{\mathrm{IV}} \mathrm{O}_{3}\left(\mathrm{CH}_{3} \mathrm{COO}\right)_{3}\left(A-\alpha-\mathrm{SiW}_{9} \mathrm{O}_{34}\right)\right]^{6-}$ displays 
photocatalytic water oxidation properties. ${ }^{19}$ In the same year, Su and coworkers showed that the dimanganese(III)-incorporated $\delta$-Dawson ion $\left[\left(\mathrm{WO}_{5}\right)_{3} \mathrm{~W}_{14} \mathrm{Mn}^{\mathrm{IIII}}{ }_{2} \mathrm{O}_{44} \mathrm{Cl}_{2}\right]^{12-}$ catalyzes hydrogen evolution. ${ }^{6 f}$

Our group has been interested for many years in the synthesis and characterization of discretemolecular heteropolytungstates containing high-nuclearity 3d-metal assemblies. For example, we have reported the $\left\{\mathrm{Co}_{16}\right\}$-containing 36-tungsto-4-phosphate, -silicate and -germanate $\left[\left\{\mathrm{Co}_{4}(\mathrm{OH})_{3} \mathrm{PO}_{4}\right\}_{4}\left(A-\alpha-\mathrm{XW}_{9} \mathrm{O}_{34}\right)_{4}\right]^{32-}(\mathrm{X}=\mathrm{P}, \mathrm{Si}, \mathrm{Ge})$, each composed of four $\left\{\mathrm{Co}_{3} \mathrm{XW}_{9}\right\}$ units connected in a tetrahedral fashion to a $\left\{\mathrm{Co}_{4} \mathrm{O}_{4}\right\}$ cubane unit via four $\left\{\mathrm{PO}_{4}\right\}$ groups. ${ }^{20}$ These assemblies proved to possess single molecule magnet (SMM) behavior. Meanwhile, Wang and coworkers have shown that these compounds can act as water oxidation catalysts. ${ }^{21}$ Recently, we reported the iron(III) analogues $\left[\mathrm{Na}_{2} \mathrm{Fe}_{14}(\mathrm{OH})_{12}\left(\mathrm{PO}_{4}\right)_{4}\left(A-\alpha-\mathrm{XW}_{9} \mathrm{O}_{34}\right)_{4}\right]^{20-}(\mathrm{X}=\mathrm{Si}, \mathrm{Ge})$, where the inner cubane is heterometallic being occupied by two iron and two sodium ions. ${ }^{22}$ All these polyanions were synthesized in the presence of phosphate ions and in basic aqueous medium, which is somewhat unusual for the synthesis of transition metal containing POMs, as mostly acidic conditions are preferable.

As a continuation of our work on $\left\{\mathrm{M}_{16}\right\}$-containing polyanions, we report herein the synthesis and characterization of two mixed-valence $\mathrm{Mn}_{16}$-containing 36-tungsto-4-silicates. Experimental

\section{Section}

Materials and Physical Measurements. The precursor salt $\mathrm{Na}_{10}\left[A-\alpha-\mathrm{SiW}_{9} \mathrm{O}_{34}\right] \cdot 23 \mathrm{H}_{2} \mathrm{O}$ was prepared according to the published procedure and characterized by FT-IR spectroscopy. ${ }^{23}$ All other reagents were used as purchased without further purification. Infrared spectra were recorded on a Nicolet Avatar 370 FT-IR spectrophotometer using KBr pellets. The following abbreviations were used to assign peak intensities: $\mathrm{w}=$ weak, $\mathrm{m}=$ medium, and $\mathrm{s}=$ strong. Thermogravimetric 
analysis was carried out on a TA Instruments SDT Q600 thermobalance with a $100 \mathrm{~mL} / \mathrm{min}$ flow of nitrogen; the temperature was ramped from room temperature to $500{ }^{\circ} \mathrm{C}$ at a rate of $5{ }^{\circ} \mathrm{C} / \mathrm{min}$. Elemental analysis for NaCs-1 and NaRb-2 was performed by CNRS, Service Central d'Analyze, Solaize, France.

Synthesis of $\left.\mathrm{Na}_{19.5} \mathrm{Cs} 8.5\left[\mathrm{Mn}_{10}^{I I I} \mathrm{Mn}_{6}^{I I} \mathrm{O}_{6}(\mathrm{OH})_{6}\left(\mathrm{PO}_{4}\right)_{4}\right\}\left(\mathrm{A}-\alpha-\mathrm{Si}_{9} \mathrm{O}_{34}\right)_{4}\right] \cdot 90 \mathrm{H}_{2} \mathrm{O}(\mathrm{NaCs}-1)$. То а solution of $\mathrm{Mn}\left(\mathrm{OOCCH}_{3}\right)_{3} \cdot 2 \mathrm{H}_{2} \mathrm{O}(0.32 \mathrm{~g}, 1.19 \mathrm{mmol})$ in $20 \mathrm{~mL} \mathrm{H}_{2} \mathrm{O}, 0.50 \mathrm{~g}(0.17 \mathrm{mmol}) \mathrm{Na}_{10}[A$ $\left.\alpha-\mathrm{SiW}_{9} \mathrm{O}_{34}\right] \cdot 23 \mathrm{H}_{2} \mathrm{O}$ was added and stirred until a clear dark solution was obtained. The $\mathrm{pH}$ of the mixture was then raised to 9 by adding solid Na3PO4 and stirred for 2 hours at room temperature. The turbid black-brown solution was centrifuged (10 min at $4000 \mathrm{rpm}$ ) and then decanted. A few drops of $1 \mathrm{M} \mathrm{CsCl}$ solution were added to the clear solution, which was then allowed to evaporate in an open vial at room temperature. After about a week, a brown crystalline product appeared, which was collected by filtration and air-dried. Yield $140 \mathrm{mg}(57 \%)$. IR (2\% KBr pellet, v/cm $\left.{ }^{-1}\right)$ : 1090(m), 944(w), 943(m) 742(m), 899(m), 798(w), 723(w), 524(w), see Figure S1. Elemental analysis (\%) for $\mathrm{Na}_{19.5} \mathrm{Cs}_{8.5}\left[\left\{\mathrm{Mn}_{10}^{\mathrm{III}} \mathrm{Mn}_{6}{ }_{6} \mathrm{O}_{6}(\mathrm{OH})_{6}\left(\mathrm{PO}_{4}\right)_{4}\right\}\left(A-\alpha-\mathrm{SiW}_{9} \mathrm{O}_{34}\right)_{4}\right] \cdot 90 \mathrm{H}_{2} \mathrm{O}$, calculated (found): Na 3.31 (3.57), Cs 8.33 (8.40), P 0.91 (0.96), Mn 6.48 (6.20), W 48.79 (48.30), Si 0.83 (0.86).

Synthesis of $\quad \mathrm{Na}_{18} \mathrm{Rb}_{10}\left[\mathrm{Mn}^{\mathrm{III}}{ }_{4} \mathrm{Mn}^{\mathrm{II}}{ }_{12}(\mathrm{OH})_{12}\left(\mathrm{PO}_{4}\right)_{4}\left(\mathrm{~A}-\alpha-\mathrm{SiW}_{9} \mathrm{O}_{34}\right)_{4}\right] \cdot 75 \mathrm{H}_{2} \mathrm{O} \quad(\mathrm{NaRb}-2)$. $\mathrm{MnCl}_{2} \cdot 4 \mathrm{H}_{2} \mathrm{O}(0.24 \mathrm{~g}, 1.21 \mathrm{mmol})$ was dissolved in $20 \mathrm{~mL} \mathrm{H} \mathrm{H}_{2} \mathrm{O}$, and then $\mathrm{Na}_{10}[A-\alpha-$ $\left.\mathrm{SiW}_{9} \mathrm{O}_{34}\right] \cdot 23 \mathrm{H}_{2} \mathrm{O}(0.50 \mathrm{~g}, 0.17 \mathrm{mmol})$ was added. The $\mathrm{pH}$ of the solution was adjusted to 9 by addition of solid $\mathrm{Na}_{3} \mathrm{PO}_{4}$, and then the resulting dark brown solution was stirred for 1 hour at room temperature. After filtration, 3-4 drops of $1.0 \mathrm{M} \mathrm{RbCl}$ solution were added to the filtrate, which was allowed to evaporate in an open vial at room temperature. Dark brown crystals started to appear after a week, which were then collected by filtration and air-dried. Yield $120 \mathrm{mg}(53 \%)$. IR 
$\left(2 \% \mathrm{KBr}\right.$ pellet, $\left.v / \mathrm{cm}^{-1}\right):$ 1096(m), 988(w), 938(w), 891(m), 806(m), 714(w), 518(w), see Figure

S1. Elemental analysis (\%) for $\mathrm{Na}_{18} \mathrm{Rb}_{10}\left[\mathrm{Mn}^{\mathrm{II}}{ }_{12} \mathrm{Mn}^{\mathrm{III}}{ }_{4}(\mathrm{OH})_{12}\left(\mathrm{PO}_{4}\right)_{4}\left(A-\alpha-\mathrm{SiW}_{9} \mathrm{O}_{34}\right)_{4}\right] \cdot 75 \mathrm{H}_{2} \mathrm{O}$ calculated (found): Na 3.20 (3.48), Rb 6.57 (6.84), P 0.95 (1.00), Mn 6.76 (6.44), W 50.95 (50.00), Si $0.86(0.89)$.

Synthesis of SBA-15. $8.0 \mathrm{~g}$ of $\mathrm{P}_{123}$ gel (Sigma-Aldrich) were added to $40 \mathrm{ml}$ of $2 \mathrm{M} \mathrm{HCl}$ and 208 $\mathrm{ml} \mathrm{H} \mathrm{H}_{2} \mathrm{O}$. This mixture was stirred initially for $2 \mathrm{~h}$ in a water bath at $35^{\circ} \mathrm{C}$ until it was completely dissolved. Then $18 \mathrm{ml}$ of tetraethylorthosilicate (TEOS) was added dropwise, and the mixture was kept stirring for $4 \mathrm{~h}$. Afterwards, the mixture was heated in an oven at $95{ }^{\circ} \mathrm{C}$ for 3 days. The white precipitate was collected by filtration, washed and then air-dried. Finally, a calcination step was performed and the as-synthesized material was heated to $550{ }^{\circ} \mathrm{C}$ at a rate of $1-2^{\circ} \mathrm{C} \min ^{-1}$ and kept at this temperature for $6 \mathrm{~h}$ to remove the templates.

Synthesis of SBA-15-apts. $1.61 \mathrm{ml}$ of 3-aminopropyltriethoxysilane (apts) was added to $3 \mathrm{~g}$ of SBA-15 in $90 \mathrm{ml}$ toluene. This mixture was refluxed for $5 \mathrm{~h}$ and then filtered at room temperature. The obtained modified SBA-15-apts was then heated at $100{ }^{\circ} \mathrm{C}$ for $5 \mathrm{~h}$.

Synthesis of SBA-15-apts-1 and SBA-15-apts-2. Both compounds (NaCs-1 and NaRb-2) (10 $\mathrm{wt} \%$ ) were separately dissolved in water resulting in brown solutions. While stirring, SBA-15-apts (90 wt\%) was slowly added and the solutions were kept stirring for $24 \mathrm{~h}$. The solutions were then filtered and washed 3 times with water. The filtrates were colorless, indicating that both POMs were quantitatively loaded on the support. The obtained products were then collected and air-dried. Additionally, the observed decrease of the BET surface area shown in Table S3 is a clear indication that apts was grafted in the mesochannels of SBA-15, followed by immobilization of $\mathbf{1}$ and $\mathbf{2}$, respectively. 
X-Ray Crystallography: Single crystals of NaCs-1 and NaRb-2 were mounted on a Hampton cryoloop in light oil for data collection at $100 \mathrm{~K}$. A Bruker D8 SMART APEX II CCD diffractometer with kappa geometry and Mo-K $\alpha$ radiation (graphite monochromator, $\lambda=0.71073$ $\AA$ ) was used for indexing and data collection. Data integration was performed using SAINT ${ }^{24}$ and routine Lorentz and polarization corrections were applied. Multiscan absorption corrections were performed using SADABS. ${ }^{25}$ Direct methods (SHELXS97) successfully located the tungsten atoms, and successive Fourier syntheses (SHELXL2013) revealed the remaining atoms. ${ }^{26}$ Refinements were full-matrix least-squares against $\left|\mathrm{F}^{2}\right|$ using all data. In the final refinement, all non-disordered heavy atoms ( $\mathrm{Na}, \mathrm{Cs}, \mathrm{Rb}, \mathrm{Mn}, \mathrm{Si}, \mathrm{W}$ ) were refined anisotropically; oxygen atoms and disordered counter-cations were refined isotropically. No hydrogen atoms were included in the models. Single crystal XRD refinements showed the presence of one potassium cation in the solid lattice of NaCs-1, which was not detected by elemental analysis. We believe this to be a localized impurity within the crystal, as no potassium cation has been used throughout the synthesis and isolation of the product. Crystallographic data are summarized in Table S1 (Supporting Information). Further details on the crystal structure investigations may be obtained from the Fachinformationszentrum Karlsruhe, 76344 EggensteinLeopoldshafen,Germany(fax:(+49)7247-808-666;e-mail:crysdata@fiz-karlsruhe.de),on quoting the depository numbers 429913 (for NaCs-1) and 429914 (for NaRb-2).

XAS Measurements. The $\mathrm{Mn} \mathrm{L}_{2,3}$ edge X-ray absorption spectroscopy (XAS) was performed at beamline 6.3.1 of the Advanced Light Source at Lawrence Berkeley National Laboratory, USA. The spectra were taken with the sample at room temperature. Linear polarized light and total electron yield as detection mode were used. 
Magnetic Susceptibility Measurements. The magnetic susceptibility measurements were obtained on a Quantum Design SQUID magnetometer MPMS-XL. This magnetometer works between 1.8 and $400 \mathrm{~K}$ for $d c$ applied fields ranging from -7 to $+7 \mathrm{~T}$. Measurements were performed on polycrystalline samples. The magnetic data were corrected for the sample holder and the diamagnetic contribution.

Electrochemical Measurements. The electrochemical set-up was a CHI660E driven by a PC with the CHI software. Potentials are quoted against a saturated calomel electrode (SCE). The counter electrode was a platinum gauze of large surface area. The working electrode was an ITO plate $(0.3$ $\mathrm{cm}^{2}$ ). All experiments were performed at room temperature. The solutions were deaerated thoroughly for at least 30 min with pure argon and kept under a positive pressure of this gas during the experiments.

Catalytic Oxidation. Oxidation of cyclohexene (49 mmol, $5 \mathrm{ml}$ ) under a constant airflow (about $5 \mathrm{ml} / \mathrm{min}$ ) and in the presence of $45 \mathrm{mg}$ of catalyst (1 and $\mathbf{2}$ supported on the modified mesoporous support SBA-15-apts) was carried out in a temperature-controlled glass vessel at $70^{\circ} \mathrm{C}$ in toluene $(10 \mathrm{ml})$. After the reaction, the solution was allowed to cool to room temperature and then samples were taken for GC analysis. A GC-2010 Shimadzu instrument equipped with a flame ionization detector and HP-FFAP column (50 m x $0.32 \mathrm{~mm})$ was used. The carrier gas was He. The analysis of substrate loss was below $5 \%$.

Battery performance. The composite electrodes were prepared by mixing the active material (NaCs-1 and NaRb-2, respectively), carbon black (super P), and poly(vinylidene fluoride) (PVDF) binder in a weight ratio of $60: 20: 20$ with N-methylpyrrolidinone (NMP) to form a slurry. The mixture was coated onto copper foil using a doctor blade with a height of $75 \mathrm{~mm}$ and then dried in air at $80{ }^{\circ} \mathrm{C}$ to remove the solvent. The electrodes were roll-pressed and then punched 
into pieces of diameter $16 \mathrm{~mm}$. These punched electrodes were dried at $110{ }^{\circ} \mathrm{C}$ under vacuum for 4 hours before transferring to a glovebox. Then the electrodes were assembled in 2016 coin cells with circular metallic lithium metal (diameter $16 \mathrm{~mm}$ ) as counter electrode, glass fiber (Whatman, diameter $19 \mathrm{~mm}$ ) as separator, and $1 \mathrm{M} \mathrm{LiPF}_{6}$ in a mixture of ethylene carbonate $(\mathrm{EC})$ and diethyl carbonate (DEC) (1:1 weight \%) as electrolyte. Cyclic voltammetry was performed with a Biologic VMP3 potentiostat in the range of $0.01 \mathrm{~V}-2.0 \mathrm{~V}$ vs. $\mathrm{Li}^{2} \mathrm{Li}^{+}$with a scan rate of $0.1 \mathrm{mV} \mathrm{s}^{-1}$. A Neware battery tester was used for galvanostatic charge / discharge tests in the range of $0.01 \mathrm{~V}-$ $2.0 \mathrm{~V} v s \mathrm{Li} / \mathrm{Li}^{+}$at a current density of $100 \mathrm{~mA} \mathrm{~g}^{-1}$.

\section{Results and Discussion}

Synthesis and Structure. Reaction of $\mathrm{Mn}\left(\mathrm{OOCCH}_{3}\right)_{3} \cdot 2 \mathrm{H}_{2} \mathrm{O}$ and $\mathrm{MnCl}_{2} \cdot 4 \mathrm{H}_{2} \mathrm{O}$ with $\mathrm{Na}_{10}[A-\alpha-$ $\left.\mathrm{SiW}_{9} \mathrm{O}_{34}\right] \cdot 23 \mathrm{H}_{2} \mathrm{O}^{23}$ in $7: 1$ and 6:1 ratios, respectively, resulted in the 16-manganese-containing, mixed-valent, $\quad$ Keggin-based $\quad 36$-tungsto-4-silicates $\quad\left[\mathrm{Mn}^{\mathrm{III}}{ }_{10} \mathrm{Mn}_{6}{ }_{6} \mathrm{O}_{6}(\mathrm{OH})_{6}\left(\mathrm{PO}_{4}\right)_{4}(A-\alpha\right.$ $\left.\left.\mathrm{SiW}_{9} \mathrm{O}_{34}\right)_{4}\right]^{28-}$ (1) and $\left[\mathrm{Mn}_{4}{ }_{4}{ }_{4} \mathrm{Mn}^{\mathrm{II}}{ }_{12}(\mathrm{OH})_{12}\left(\mathrm{PO}_{4}\right)_{4}\left(A-\alpha-\mathrm{SiW}_{9} \mathrm{O}_{34}\right)_{4}\right]^{28-}$ (2), respectively. Both reactions were carried out in aqueous medium at $\mathrm{pH} 9$ and in the presence of phosphate ions. Polyanion 1 was isolated as the hydrated sodium-cesium salt $\mathrm{Na}_{19.5} \mathrm{Cs} 8.5\left[\left\{\mathrm{Mn}_{10}^{\mathrm{III}}{ }_{10} \mathrm{Mn}_{6}{ }_{6} \mathrm{O}_{6}(\mathrm{OH})_{6}\left(\mathrm{PO}_{4}\right)_{4}\right\}\left(A-\alpha-\mathrm{SiW}_{9} \mathrm{O}_{34}\right)_{4}\right] \cdot 90 \mathrm{H}_{2} \mathrm{O}(\mathbf{N a C s}-1)$, whereas polyanion 2 was isolated as the sodium-rubidium salt $\mathrm{Na}_{18} \mathrm{Rb}_{10}\left[\mathrm{Mn}^{\mathrm{III}}{ }_{4} \mathrm{Mn}^{\mathrm{II}}{ }_{12}(\mathrm{OH})_{12}\left(\mathrm{PO}_{4}\right)_{4}(A-\alpha-\right.$ $\left.\left.\mathrm{SiW}_{9} \mathrm{O}_{34}\right)_{4}\right] \cdot 75 \mathrm{H}_{2} \mathrm{O}(\mathbf{N a R b}-2)$. The chemical composition including counter cations and crystal waters was confirmed by elemental and thermogravimetric analyses (see Experimental Section). Single crystal X-ray diffraction analyses revealed that polyanions $\mathbf{1}$ and $\mathbf{2}$ crystallized in the orthorhombic Pmmn and monoclinic $C 2 / c$ space groups, respectively. Both polyanions $\mathbf{1}$ and $\mathbf{2}$ are isostructural (Figure 1), each containing $16 \mathrm{Mn}$ centers, but the exact number of $\mathrm{Mn}^{3+}$ and $\mathrm{Mn}^{2+}$ ions is different (see Figure 2): $10 \mathrm{Mn}^{3+} / 6 \mathrm{Mn}^{2+}$ in $\mathbf{1} v s 4 \mathrm{Mn}^{3+} / 12 \mathrm{Mn}^{2+}$ in 2 (vide infra). The 
structures of 1 and 2 comprise a central $\left\{\mathrm{Mn}_{4} \mathrm{O}_{4}\right\}$ cubane unit capped by four tri-manganesesubstituted $\left\{\mathrm{Mn}_{3}\left(A-\alpha-\mathrm{SiW}_{9}\right)\right\}$ Keggin units, the overall assembly being connected by four phosphate $\left\{\mathrm{PO}_{4}\right\}$ linkers (Figure 1).

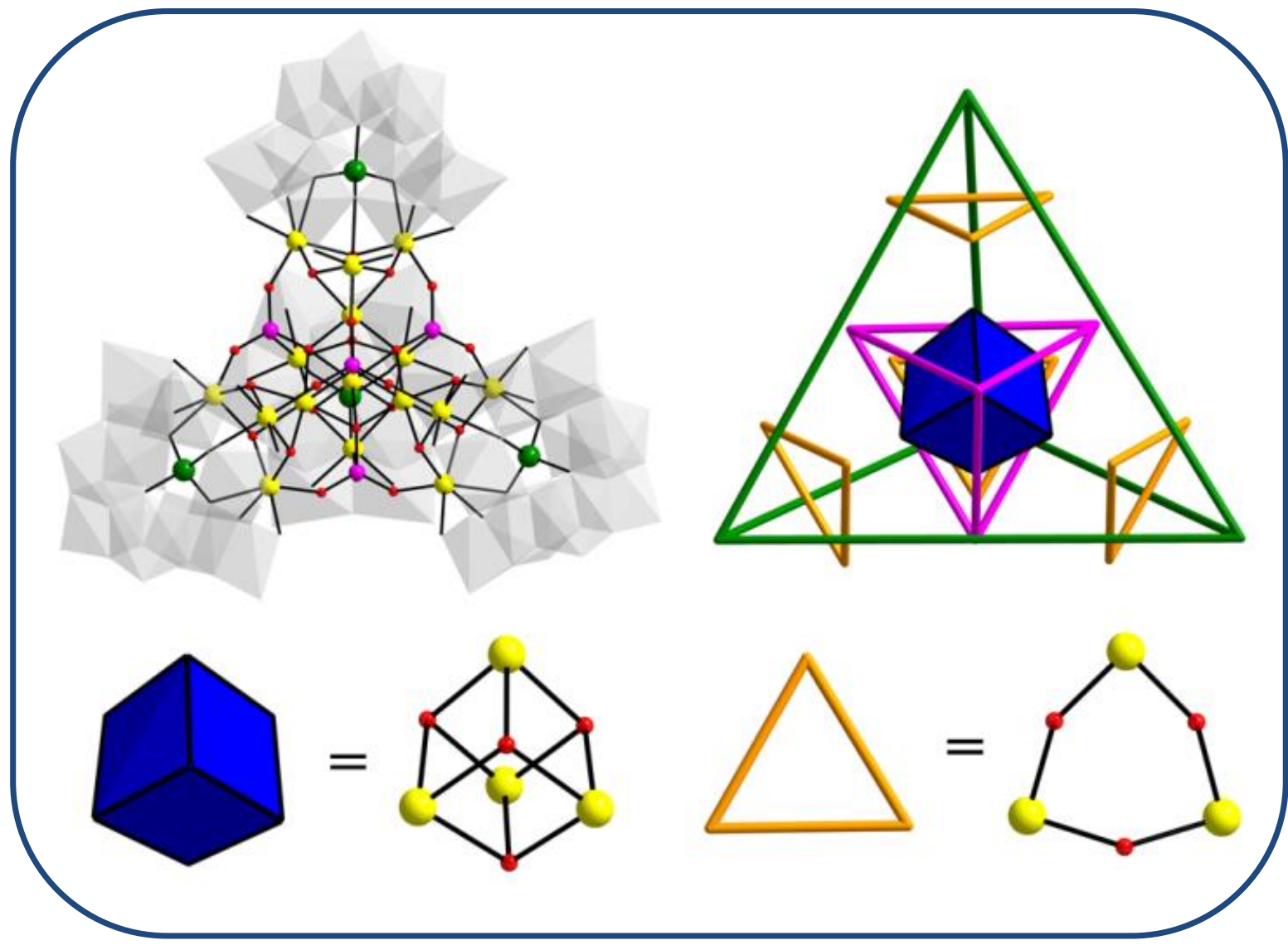

Figure 1. Top left: Combined polyhedral/ball-and-stick representation of polyanions $\mathbf{1}$ and 2. Top right: Representation of various tetrahedral building units in 1 and 2. Color code: $\mathrm{WO}_{6}$ octahedra (white), $\mathrm{Mn}^{\mathrm{II}} / \mathrm{Mn}^{\mathrm{III}}$ (yellow), P (pink), Si (green), O (red). 


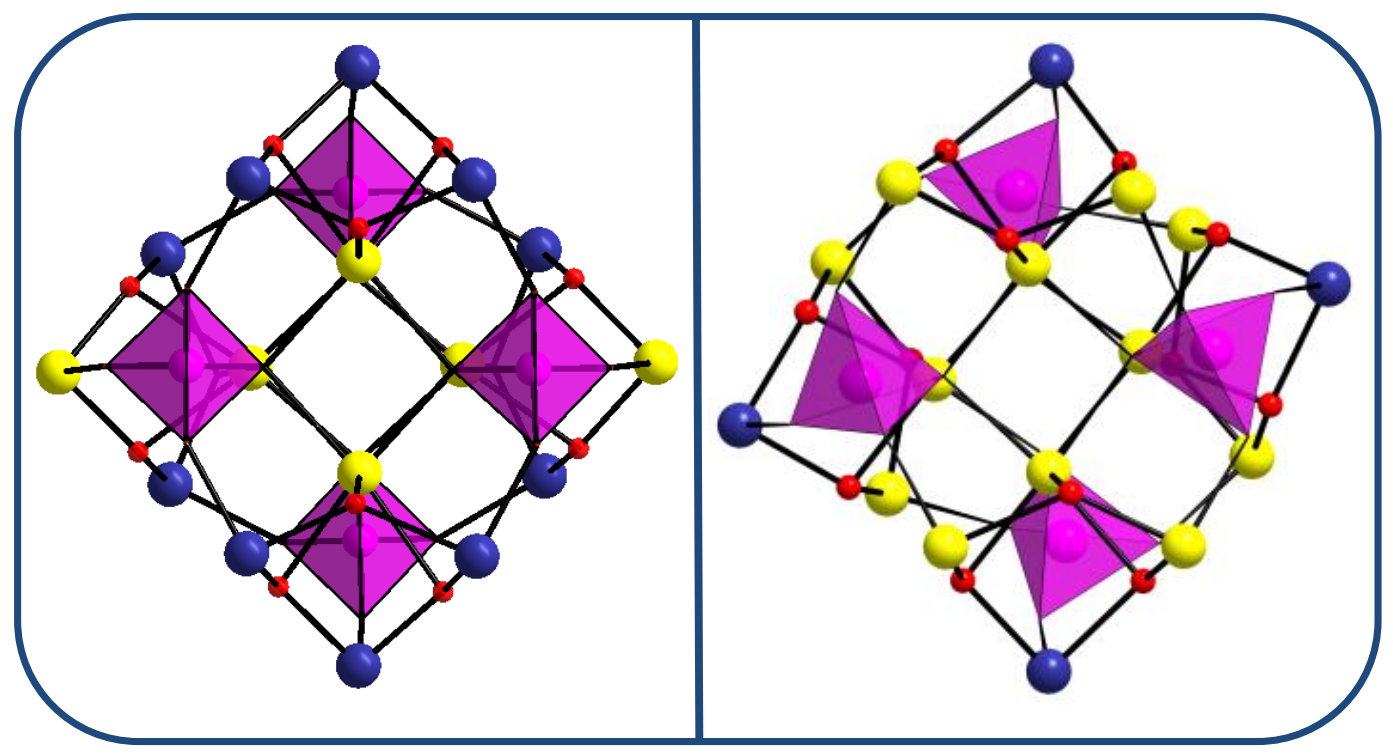

Figure 2. Ball-and-stick representation of the cationic manganese-oxo cores $\left\{\mathrm{Mn}^{\mathrm{III}}{ }_{10} \mathrm{Mn}_{6}{ }_{6} \mathrm{O}_{6}(\mathrm{OH})_{6}\left(\mathrm{PO}_{4}\right)_{4}\right\}^{12+}$ in $\mathbf{1}(\mathrm{left})$ and $\left\{\mathrm{Mn}^{\mathrm{III}}{ }_{4} \mathrm{Mn}_{12}^{\mathrm{II}}(\mathrm{OH})_{12}\left(\mathrm{PO}_{4}\right)_{4}\right\}^{12+}$ in 2 (right). Color code: $\mathrm{Mn}^{\mathrm{II}}$ (yellow), $\mathrm{Mn}^{\mathrm{III}}$ (indigo), $\mathrm{O}$ (red).

Bond valence sum (BVS) calculations ${ }^{27}$ (Table S2) indicated that for polyanion 1 the four manganese centers in the central $\left\{\mathrm{Mn}_{4} \mathrm{O}_{4}\right\}$ cubane unit all have a $2+$ oxidation state. In the capping $\left\{\mathrm{Mn}_{3}\left(\mathrm{SiW}_{9}\right)\right\}$ Keggin units 10 out of 12 manganese ions have a $3+$ oxidation state, with the two $\mathrm{Mn}^{2+}$ ions being located in two different Keggin units, which are related to each other by a mirror plane. Hence, 1 contains a total of ten $\mathrm{Mn}^{3+}$ and six $\mathrm{Mn}^{2+}$ ions. Furthermore, in each $\left\{\mathrm{Mn}_{3}\left(\mathrm{SiW}_{9}\right)\right\}$ Keggin unit of 1, the oxygen atoms bridging the manganese centers all have a BVS value of ca. 1.5, which we assigned as 50:50\% oxo/hydroxo, resulting in a cationic $\left\{\mathrm{Mn}^{\mathrm{III}}{ }_{10} \mathrm{Mn}_{6}^{\mathrm{II}}{ }_{6} \mathrm{O}_{6}(\mathrm{OH})_{6}\right\}^{24+}$ core, and an overall charge of 28-for polyanion 1, which is balanced in the solid state by 19.5 sodium and 8.5 cesium counter cations, as confirmed by elemental analysis (see Experimental Section). 
BVS on polyanion 2 revealed that all four manganese centers in the central $\left\{\mathrm{Mn}_{4} \mathrm{O}_{4}\right\}$ cubane unit have a $2+$ oxidation state, in analogy with 1 . Each of the four capping $\left\{\mathrm{Mn}_{3}\left(\mathrm{SiW}_{9}\right)\right\}$ units contains one $\mathrm{Mn}^{3+}$ and two $\mathrm{Mn}^{2+}$ ions, so polyanion 2 has a total of four $\mathrm{Mn}^{3+}$ and twelve $\mathrm{Mn}^{2+}$ ions (Table S2). All oxygen atoms bridging the manganese centers in the $\left\{\mathrm{Mn}_{3}\left(\mathrm{SiW}_{9}\right)\right\}$ Keggin units of $\mathbf{2}$ are monoprotonated and hence hydroxo ligands. This results in a cationic $\left\{\mathrm{Mn}^{\mathrm{III}}{ }_{4} \mathrm{Mn}^{\mathrm{II}}{ }_{12}(\mathrm{OH})_{12}\right\}^{24+}$ core, and an overall charge of 28 - for polyanion $\mathbf{2}$, which is balanced in the solid state by 18 sodium and 10 rubidium counter cations, as confirmed by elemental analysis (see Experimental Section).

It deserves attention that the manganese-oxo clusters in $\mathbf{1}\left(\left\{\mathrm{Mn}^{\mathrm{III}}{ }_{10} \mathrm{Mn}_{6}{ }_{6} \mathrm{O}_{6}(\mathrm{OH})_{6}\right\}^{24+}\right)$ and $\mathbf{2}$ $\left(\left\{\mathrm{Mn}^{\mathrm{III}}{ }_{4 \mathrm{Mn}^{\mathrm{II}}}{ }_{12}(\mathrm{OH})_{12}\right\}^{24+}\right)$ have the exact same positive charge of $24+$, in spite of different numbers of $\mathrm{Mn}^{3+}$ and $\mathrm{Mn}^{2+}$ ions, but different degrees of protonation for $\mathbf{1}$ (6 protons) and $\mathbf{2}$ (12 protons) counterbalance this effect. It is also worth noting that the $\left\{\mathrm{Mn}_{4} \mathrm{O}_{4}\right\}$ cubane cores in both polyanions $\mathbf{1}$ and $\mathbf{2}$ contain exclusively $\mathrm{Mn}^{2+}$ ions, resulting in a neutral assembly. This is fully consistent with our earlier reported $\left\{\mathrm{Co}_{16}\right\}$ and $\left\{\mathrm{Fe}_{14} \mathrm{Na}_{2}\right\}$ analogues, which have $\left\{\mathrm{Co}_{4}{ }_{4} \mathrm{O}_{4}\right\}$ and $\left\{\mathrm{Fe}^{\mathrm{III}}{ }_{2} \mathrm{Na}_{2} \mathrm{O}_{4}\right\}$ cores, respectively. ${ }^{20,22}$

The different mixed-valence nature of polyanions $\mathbf{1}$ and $\mathbf{2}$ has structural consequences, leading to a pronounced distortion within the $\left\{\mathrm{Mn}_{16}\right\}$ cores as well as the polyanions overall, as seen in Figures 2. Polyanion 2 displays an overall 'twisted' tetrahedral arrangement, as compared to the more ideal tetrahedral one for polyanion $\mathbf{1}$. This reduction in symmetry is also reflected in the monoclinic space group C2/c for NaRb-2, compared to the orthorhombic space group Pmmn for NaCs-1, and the former also has more IR signals, resulting in a broader spectrum (see Figure S1). All manganese centers in $\mathbf{1}$ and $\mathbf{2}$ exhibit a distorted octahedral coordination geometry, and the respective $\mathrm{Mn}^{\mathrm{II}}$-O bond lengths are in the range of 2.066(17) - 2.413(11) $\AA$ for 1 and 2.070(16) - 
2.463(14) $\AA$ for 2, whereas the Mn ${ }^{\mathrm{III}}-\mathrm{O}$ bond lengths are in the range of 1.896(4) $-2.325(8) \AA \AA$ for 1 and 1.902(15) - 2.367(14) $\AA$ for 2, which indicates the expected shorter bond lengths for manganese in the higher oxidation state. Moreover, the respective trans $\mathrm{O}-\mathrm{Mn}-\mathrm{O}$ bond angles are in the range of $157.9(3)-176.8(4)$ for $\mathbf{1}$ and $160.7(5)$ - 175.2(6) for $\mathbf{2}$, whereas the cis O-Mn-O bond angles are in the range of 70.0(4) - 103.0(4) for $\mathbf{1}$ and 70.6(5) - 107.5(5) for 2.

With respect to the synthetic procedures of $\mathbf{1}$ and $\mathbf{2}$, three points were crucial in order to successfully synthesize and isolate the desired products in best yield. Firstly, solid $\mathrm{Na}_{3} \mathrm{PO}_{4}$ had to be added slowly to the reaction mixture, after dissolution of all other reactants, until the $\mathrm{pH}$ reached 9, as otherwise the yield is lower. Also, if phosphate is already present before addition of the other reagents, precipitation is induced. It seems that the presence of phosphate ions at a later stage of the reaction process directs the structural reorganization of the $\left\{\mathrm{Mn}_{16}\right\}$ assembly, which is consistent with our previous work. ${ }^{15 a, 20-22,28}$ Secondly, the ratio of lacunary POM precursor to manganese ions needs to be $1: 7$ for $\mathbf{1}$ and $1: 6$ for $\mathbf{2}$ in order to obtain the highest yields, rather than the stoichiometric ratio of 1:4. Thirdly, although both polyanions 1 and $\mathbf{2}$ contain mixedvalence $\left(\mathrm{Mn}^{2+} / \mathrm{Mn}^{3+}\right)$ manganese-oxo clusters, the manganese reagents for the respective syntheses of $\mathbf{1}$ and $\mathbf{2}$ need to contain exclusively $\mathrm{Mn}^{3+}$ for $\mathbf{1}$ and $\mathrm{Mn}^{2+}$ for $\mathbf{2}$. Any attempt to reproduce $\mathbf{1}$ and 2 by using mixtures of $\mathrm{Mn}^{2+}$ and $\mathrm{Mn}^{3+}$ salts resulted in unidentified precipitates. It should be noted that the exact number of $\mathrm{Mn}^{2+}$ and $\mathrm{Mn}^{3+}$ centers is perfectly reproducible, as we have verified by performing numerous experiments.

Synthesis of 1 with exclusively $\mathrm{Mn}^{3+}$ ions implies that some manganese ions must be reduced in situ during the course of the reaction, whereas the synthesis of $\mathbf{2}$ with exclusively $\mathrm{Mn}^{2+}$ ions implies that some manganese ions must be oxidized in situ during the course of the reaction. It should be noted that both reactions were performed open to the air. Autoxidation and -reduction of 
manganese ions in aqueous solution during reactions with lacunary POMs is not unprecedented. A literature survey on manganese-containing heteropolytungstates demonstrated several examples of mixed-valence manganese centers in the final products, with manganese in a single oxidation state being used in the reactions. ${ }^{8 \mathrm{j}, 10 \mathrm{~d}, 14}$ However, preformed mixed-valence, multinuclear manganese complexes have also been used for the synthesis of mixed-valence Mn-containing POMs. ${ }^{7 \mathrm{~d}, \mathrm{e}, \mathrm{g}, 8 \mathrm{~h}, \mathrm{k}}$ Finally, the isolation process of polyanions $\mathbf{1}$ and $\mathbf{2}$ as bulk pure crystalline solids in maximum yields required the presence of cesium ions in the case of $\mathbf{1}$ and rubidium ions for $\mathbf{2}$. XAS Measurements. X-ray absorption spectra on NaCs-1 and NaRb-2 were carried out at room temperature using beamline 6.3.1 of the Advanced Light Source for linear polarized light with total electron yield as detection mode. The spectra were compared with those of the reference compounds $\left[\mathrm{Mn}_{4}{ }_{4}\left(\mathrm{C}_{12} \mathrm{H}_{9} \mathrm{~N}_{2} \mathrm{O}\right)_{6}\right]\left(\mathrm{BF}_{4}\right)_{2} \cdot 2 \mathrm{CH} 3 \mathrm{CN} \cdot \mathrm{H} 2 \mathrm{O}$ ("MnStar", only $\mathrm{Mn}^{2+}$-containing) ${ }^{29}$ and $\left[\mathrm{Mn}_{6}{ }_{6}{ }_{6}\left(\mu_{3}-\mathrm{O}\right)_{2}(\mathrm{Salox})_{6}\left(\mathrm{CH}_{3} \mathrm{CH}_{2} \mathrm{OH}\right)_{4}\left\{\left(\mathrm{CH}_{3}\right)_{3} \mathrm{CCOO}_{2}\right]\right.$ ("Mn salox", only $\mathrm{Mn}^{3+}$-containing) ${ }^{30}$ see Figure 3.

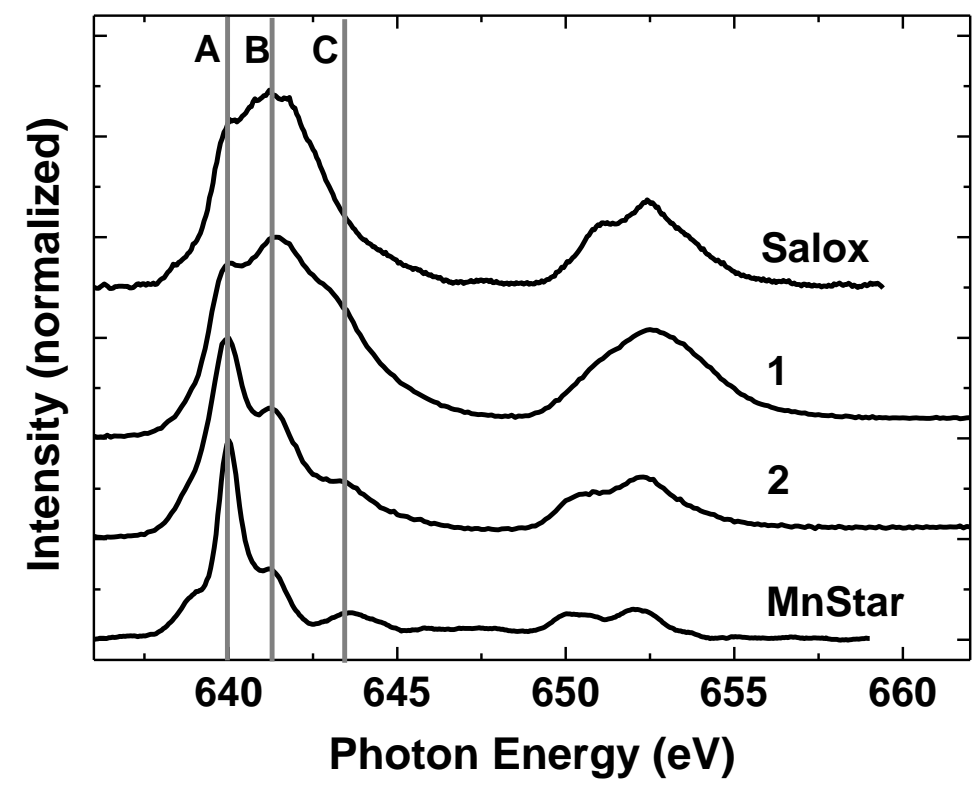


Figure 3. Manganese $\mathrm{L}_{2,3}$ edge $\mathrm{X}$-ray absorption spectra on NaCs-1 and NaRb-2. For comparison, the spectra of the exclusively $\mathrm{Mn}^{2+}$-containing "MnStar" 29 and the exclusively $\mathrm{Mn}^{3+}$-containing "Salox",30 are also displayed.

The Mn $\mathrm{L}_{3}$ edge of MnStar comprises three distinct features, namely an absolute maximum of absorption at $640 \mathrm{eV}$ (labeled A), and shoulders around $641.5 \mathrm{eV}(\mathrm{B})$ and $643.5 \mathrm{eV}(\mathrm{C})$, whereas the $\mathrm{L}_{3} \mathrm{X}$-ray absorption of Salox peaks at $641.5 \mathrm{eV}$ (B). The Mn XAS of Salox also shows a feature around $640 \mathrm{eV}$ which can be attributed to charge transfer excitations (d5L states). The L2 edge (spanning the range of $\sim 650-655 \mathrm{eV}$ ) of MnStar comprises two small but rather sharp peaks. In contrast, the $\mathrm{Mn} \mathrm{L}_{2}$ edge of Salox consists of a rather broad multiplet structure and less sharp features. The Mn L 2,3 edge XAS of NaRb-2 has its absolute maximum in intensity at $640 \mathrm{eV}$ (A), confirming that the major fraction of the $\mathrm{Mn}$ ions in $\mathbf{2}$ is divalent. However, feature $\mathrm{B}$, corresponding to the Salox $\mathrm{L}_{3}$ edge maximum is significantly more pronounced compared to MnStar, indicating also the presence of trivalent $\mathrm{Mn}$ ions in 2. In contrast, the $\mathrm{Mn} \mathrm{L}_{3}$ multiplet structure of NaCs-1 is more similar to the spectrum of Salox, confirming that the majority of the Mn ions in $\mathbf{1}$ are in a trivalent state. However, a more intense feature A and the presence of a significant feature $\mathrm{C}$ as compared to Salox suggests that also some divalent $\mathrm{Mn}$ ions are present in 1.

Magnetic Measurements. Temperature-dependent $d c$ magnetic susceptibility measurements were carried out on solid samples of polyanions $\mathbf{1}$ and $\mathbf{2}$ in the temperature range $1.8-300 \mathrm{~K}$ in a field of 1000 Oe (Figure 4). 


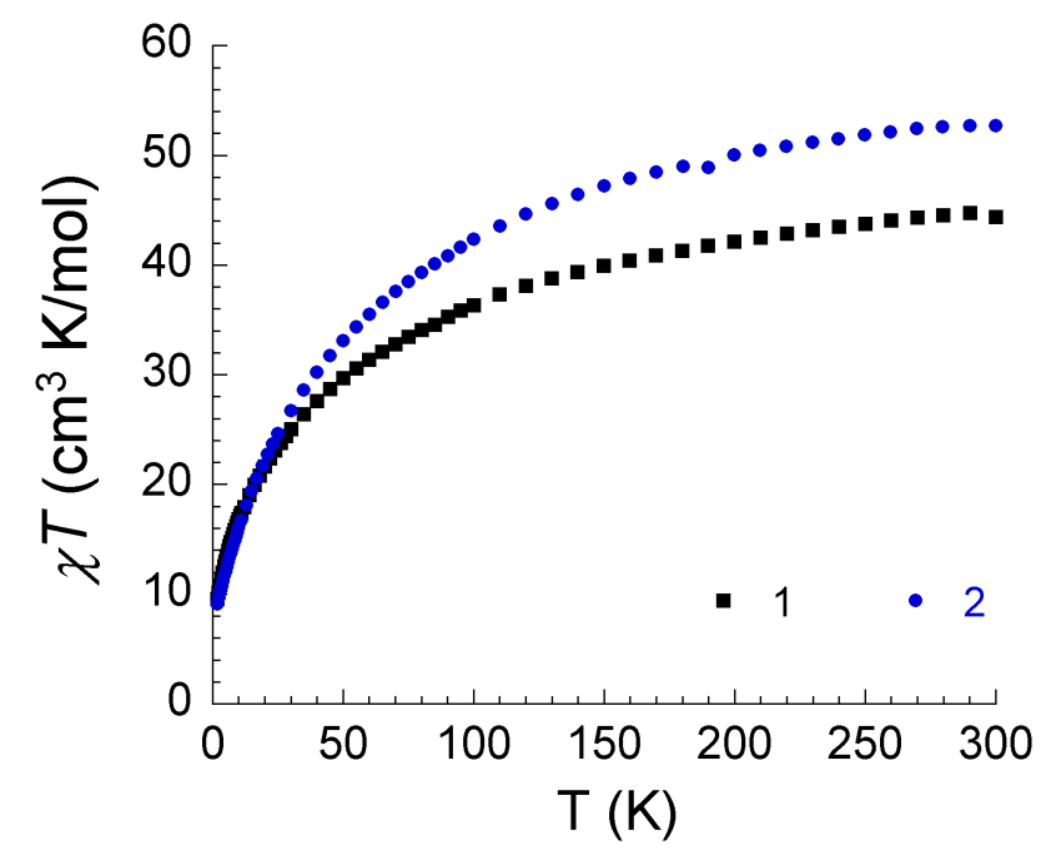

Figure 4. Temperature dependence of the $\chi \mathrm{T}$ product for polycrystalline samples of 1 (squares) and 2 (circles) at 1000 Oe.

The ${ }_{\chi \mathrm{MT}} \mathrm{T}$ value of polyanion 1 progressively decreases from $44.7 \mathrm{~cm}^{3} \mathrm{Kmol}^{-1}$ at $300 \mathrm{~K}$ to 22.8 $\mathrm{cm}^{3} \mathrm{Kmol}^{-1}$ at $\sim 40 \mathrm{~K}$ before falling rapidly to $9.6 \mathrm{~cm}^{3} \mathrm{Kmol}^{-1}$ at $1.8 \mathrm{~K}$. For polyanion 2 , the ${ }_{x \mathrm{MT}}$ values decrease from $52.8 \mathrm{~cm}^{3} \mathrm{Kmol}^{-1}$ at $300 \mathrm{~K}$ to $8.9 \mathrm{~cm}^{3} \mathrm{Kmol}^{-1}$ at $1.8 \mathrm{~K}$. The spin-only $\chi_{\mathrm{MT}} \mathrm{T}$ value for polyanion 1 comprising 10 non-interacting $\mathrm{Mn}^{3+}$ and $6 \mathrm{Mn}^{2+}$ ions is $56.25 \mathrm{~cm}^{3} \mathrm{Kmol}^{-1}$, and for polyanion 2 comprising $4 \mathrm{Mn}^{3+}$ and $12 \mathrm{Mn}^{2+}$ ions is $64.50 \mathrm{~cm}^{3} \mathrm{Kmol}^{-1}$, and hence Figure 4 is indicative of an appreciable antiferromagnetic exchange between the $\mathrm{Mn}^{3+}$ and $\mathrm{Mn}^{2+}$ centers in $\mathbf{1}$ and 2. For polyanions $\mathbf{1}$ and $\mathbf{2}$, the total spin value ranges would vary from 0 to 35 and from 0 to 38 , respectively. To determine their spin ground states, magnetization data were collected in the temperature range $2-5 \mathrm{~K}$ and in the magnetic field range $0-70000$ Oe (Figure S4). The magnetization data for both compounds do not show any saturation even at the highest field measured. Possible reasons could be the presence of magnetic spin frustration or significant zero- 
field splitting in the spin-ground state. Low-lying excited states are also anticipated for such big ions which generally have a high density of molecular spin states.

Also $a c$ susceptibility measurements were carried out in zero and non-zero $d c$ fields, but no peaks down to $1.8 \mathrm{~K}$ and no frequency-dependent in-phase and out-of-phase signals were observed (Figures S5 and S6). The latter results indicate that polyanions $\mathbf{1}$ and $\mathbf{2}$ are not single molecule magnets.

Electrochemistry. The redox behavior of $\mathbf{1}$ and $\mathbf{2}$ was studied in $\mathrm{pH} 7$ media. The UV-visible stability carried out in these media revealed that both polyanions are sufficiently stable to stand electrochemical characterization (see SI for details). Ever since the pioneering work of Pope and coworkers, ${ }^{6 a, 8 c, 31 a, b}$ numerous examples were reported on the electrochemical generation of highvalent manganese center(s) within polyoxotungstates. ${ }^{6 e, 7 \mathrm{~d}-\mathrm{g}, 13,16,18 \mathrm{a}, \mathrm{b}, 19,31 \mathrm{c}-\mathrm{f}}$ These redox processes are well-known to depend on various parameters including solvent, $\mathrm{pH}$ and composition of electrolyte. $^{31 c, d, f}$ The electrochemical generation of higher-valent multinuclear manganese complexes is an important issue because most of them can act as earth-abundant metal electrocatalysts for several challenging oxidation processes including the oxygen-evolving reaction (OER) ${ }^{7 e, 16,19,31 c, e}$ Figure $5 \mathrm{~A}$ shows the redox activity of the Mn centers of $50 \mu \mathrm{M} \mathbf{1}$ and that of the supporting electrolyte alone between $-0.880 \mathrm{~V}$ and $+1.350 \mathrm{~V}$ versus SCE at a scan rate of $100 \mathrm{mV} \mathrm{s}^{-1}$. The reduction of the $\mathrm{Mn}^{3+}$ centers to $\mathrm{Mn}^{2+}$ is represented by a broad wave peaking at $-0.040 \mathrm{~V}$ versus $\mathrm{SCE}$. On the reverse scan, the $\mathrm{CV}$ pattern features one quasi-reversible oxidation wave (at $+0.548 \mathrm{~V}$ versus SCE) preceded by a low intensity pre-wave and followed by a large irreversible wave. In agreement with previous reports, these waves are assigned to the stepwise oxidation of $\mathrm{Mn}^{2+}$ to $\mathrm{Mn}^{4+}$ and the OER, respectively. ${ }^{7,16,31 \mathrm{e}}$ The re-reduction of the $\mathrm{Mn}^{4+}$ centers to $\mathrm{Mn}^{3+}$ is also featured by a well-defined wave located at $+0.286 \mathrm{~V}$ vs. SCE. The remarkable 
outcome is that the presence of $\mathbf{1}$ makes it perfectly possible to observe the OER wave in a potential region where appreciable oxidation current does not appear on the $\mathrm{CV}$ recorded with the electrolyte alone. The variation of the Mn oxidation peak current as a function of the square root of the potential scan rate is shown in Figure 7B. The linearity of this curve demonstrates that the CVs feature a diffusion-controlled process. The Mn centers redox processes and the OER associated with $\mathbf{2}$ are also featured by well-behaved waves (Figure S8), but the oxidation potential of $\mathrm{Mn}^{2+}$ to $\mathrm{Mn}^{4+}$ in 2 is shifted in the positive direction (by $0.070 \mathrm{~V}$ ) compared to 1, which means that the latter is slightly easier to oxidize. It is worth noting that reaching the OER wave has no deleterious effect on the redox processes associated with the Mn and W centers. However, the determination of the nature of the true electrocatalyst and the study of its stability during the OER are among the main challenges and will be investigated in the future.

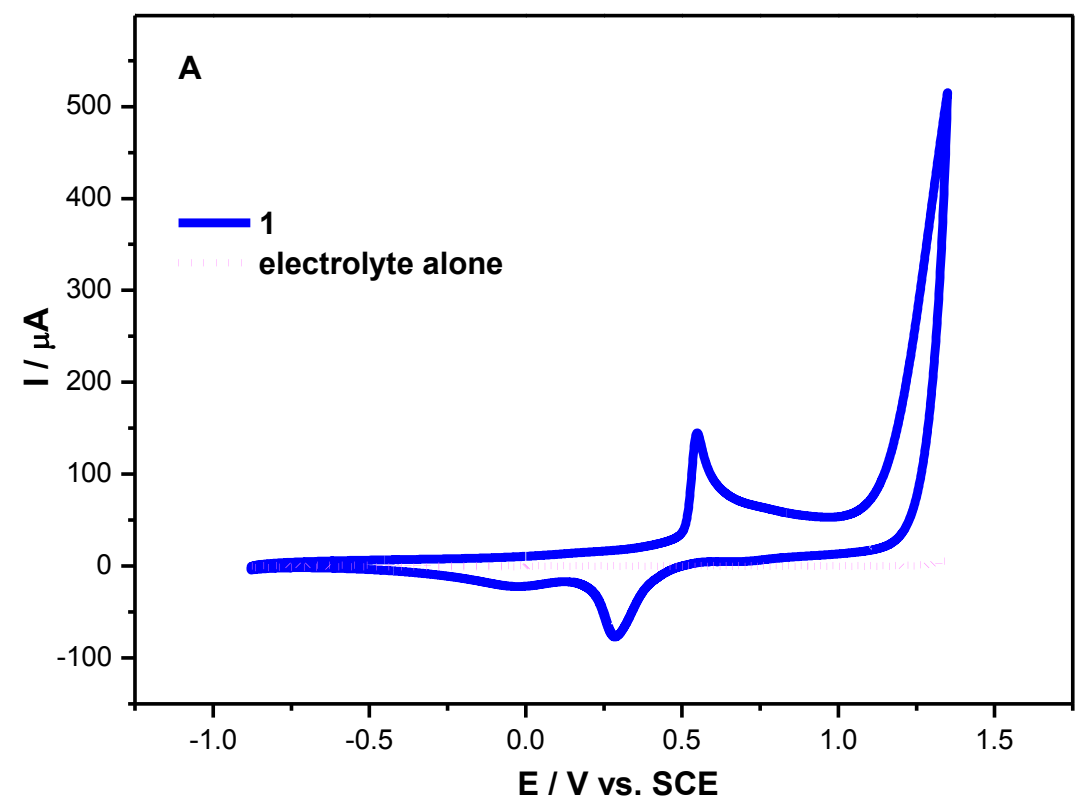




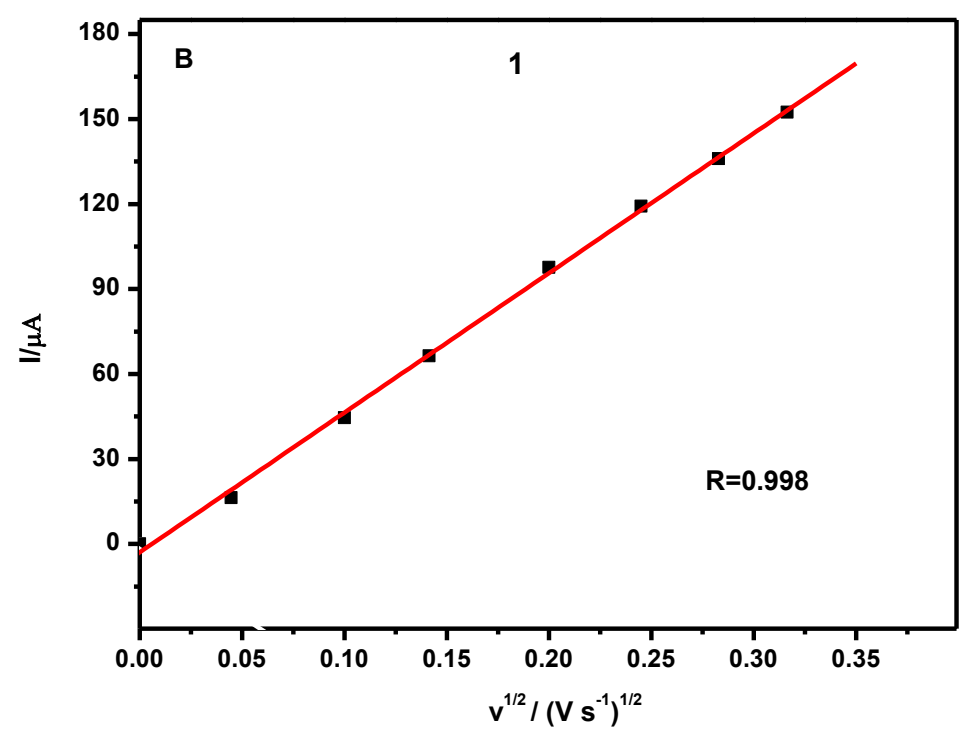

Figure 5. Redox activity of the $\mathrm{Mn}^{3+}$ and $\mathrm{Mn}^{4+}$ centers of $50 \mu \mathrm{M} 1$ in a $\mathrm{pH} 7$ medium $(1 \mathrm{M}$ $\mathrm{LiCH} 3 \mathrm{COO} / \mathrm{CH} 3 \mathrm{COOH})$. The scan rate was $100 \mathrm{mV} \mathrm{s}^{-1}$, and the reference electrode was a saturated calomel electrode (SCE). (A) Dotted pink line: background current; full blue line: cyclic voltammogram recorded in the presence of 1. (B) Variation of the Mn oxidation peak current intensity as a function of the square root of the scan rate.

The $\mathrm{W}^{6+}$ centers in $\mathbf{1}$ and $\mathbf{2}$ exhibit two quasi-reversible and well-defined reduction waves with the same general shape (Figure 6). 


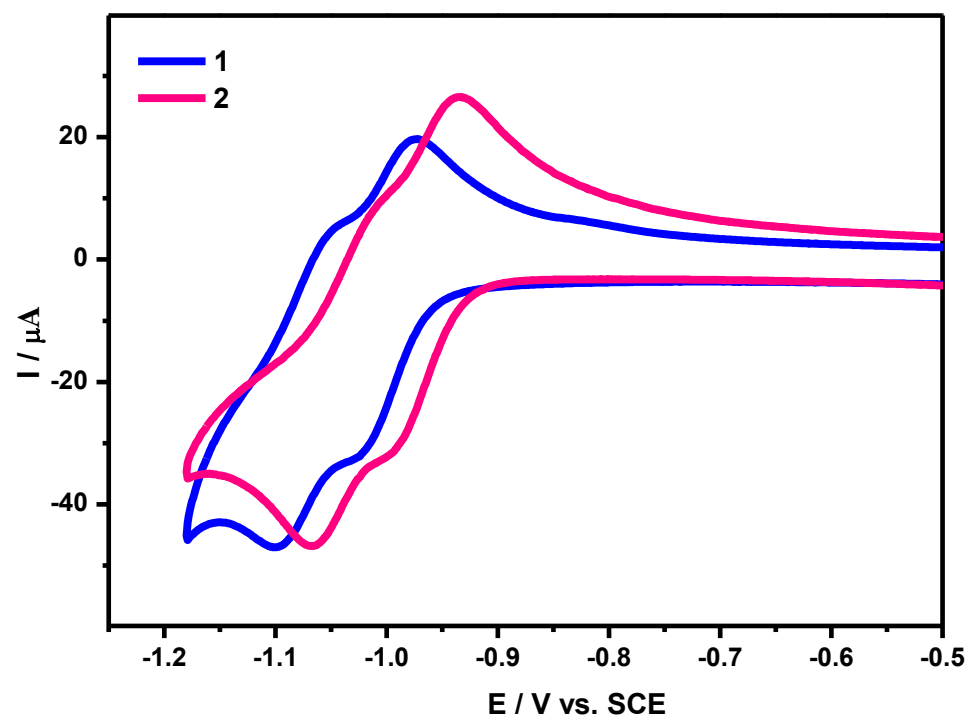

Figure 6. Cyclic voltammograms of the quasi-reversible $\mathrm{W}^{6+}$-waves of $\mathbf{1}$ and $\mathbf{2}$, respectively, run in a $\mathrm{pH} 7\left(1 \mathrm{M} \mathrm{Li} \mathrm{CH} 3 \mathrm{COO}+\mathrm{CH}_{3} \mathrm{COOH}\right)$ medium; the scan rate was $100 \mathrm{mV} \mathrm{s}^{-1}$, and the reference electrode was a saturated calomel electrode (SCE). The concentration of the polyanions was 50 $\mu \mathrm{M}$.

However, when compared to 1 , a slight anodic shift of ca. $0.035 \mathrm{~V}$ was observed for both $\mathrm{W}$ reduction waves of 2 (at ca. $-0.993 \mathrm{~V}$ and $-1.067 \mathrm{~V}$ vs. SCE respectively). It is well-known that the voltammetric behaviours of most POMs depend on several parameters including the basicity of the reduced species and, occasionally, of the fully oxidized species. ${ }^{32}$ The overpotential required for the onset of the OER $(425 \mathrm{mV})$ is lower than that observed for $\left[\mathrm{Mn}^{\mathrm{III}}{ }_{3} \mathrm{Mn}^{\mathrm{IV}} \mathrm{O}_{3}\left(\mathrm{CH}_{3} \mathrm{COO}\right)_{3}(A\right.$ $\left.\left.\alpha-\mathrm{SiW}_{9} \mathrm{O}_{34}\right)\right]^{6-}(530 \mathrm{mV}),{ }^{19}$ but the smallest value reported for a manganese-containing POM was observed for $\left[\mathrm{Mn}_{19}(\mathrm{OH})_{12}\left(\mathrm{SiW}_{10} \mathrm{O}_{37}\right)_{6}\right]^{34-}(330 \mathrm{mV}) .{ }^{16}$ It is worth noting that the electrolytes used in these reports are more acidic $(\mathrm{pH}$ 5) compared with the $\mathrm{pH} 7$ medium used here. Therefore, polyanion $\mathbf{1}$ is potentially a good candidate for efficient electrocatalysis of the OER. 
Catalysis. The heterogeneous catalytic activity of $\mathbf{1}$ and $\mathbf{2}$ for cyclohexene oxidation was carried out by loading both polyanions on a modified mesoporous support of SBA-15-apts (see details in the Experimental Section). ${ }^{33}$ The BET surface area of these supported catalysts was measured and determined to be around $350 \mathrm{~m}^{2} / \mathrm{g}$ (Table S3, see SI). According to our experiments, the desired reaction (Scheme 1) did not occur in the blank test without any catalyst or in the presence of the support alone, whether SBA-15 or SBA-15-apts.

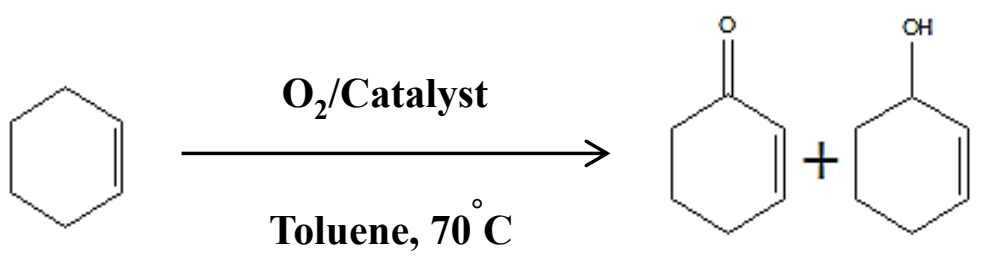

Scheme 1. Cyclohexene allylic oxidation pathway.

The homogeneous and heterogeneous catalytic oxidation of cyclohexene has been previously studied with several transition metal-modified mesoporous materials and various transition metalcontaining POMs (including manganese) under different oxidizing conditions, where the product distribution varied accordingly. ${ }^{34}$ In some cases, the corresponding epoxide of cyclohexene dominated, whereas the allylic products did in other cases. 
Table 1. Air-oxidation of cyclohexene by polyanions 1 and $\mathbf{2}$ immobilized on SBA-15-apts. ${ }^{\mathrm{a}}$

\begin{tabular}{|c|c|c|c|c|}
\hline \multirow{2}{*}{ Catalyst } & \multirow{2}{*}{$\begin{array}{l}\text { (\%) Conv. } \\
\text { Cyclohexene }\end{array}$} & \multicolumn{2}{|c|}{ Selectivity $(\%)^{b, c}$} & \multirow{2}{*}{$\begin{array}{l}\text { TOF } \\
\left(\mathbf{h}^{-1}\right)^{\mathrm{c}}\end{array}$} \\
\hline & & $\begin{array}{l}\text { Allylic } \\
\text { Ketone }\end{array}$ & $\begin{array}{l}\text { Allylic } \\
\text { Alcohol }\end{array}$ & \\
\hline SBA-15-apts-1 & 50 & 55.5 & 32.4 & 3100 \\
\hline SBA-15-apts-2 & 63 & 52.26 & 38.4 & 3740 \\
\hline
\end{tabular}

${ }^{\mathrm{a}}$ Reaction conditions: cyclohexene $(49 \mathrm{mmol}, 5 \mathrm{ml})$, toluene $10 \mathrm{ml}$, catalyst amount: $45 \mathrm{mg}, 70{ }^{\circ} \mathrm{C}, 24 \mathrm{~h}$, airflow $5 \mathrm{ml} / \mathrm{min}$. ${ }^{\mathrm{b}} \mathrm{GC}$ yield based on cyclohexene consumed. ${ }^{\mathrm{c}}$

Some other unidentified products up to $12 \% .{ }^{\mathrm{d}} \mathrm{TOF}=($ moles of consumed cyclohexene) / (moles of POM x time).

Here, the selectivity towards 2-cyclohexene-1-one was higher than 2-cyclohexene-1-ol, reaching a maximum of $52-55 \%$ and $32-38 \%$, respectively. Such product distribution, where allylic oxidation products are dominant, is typical for a homolytic oxidation mechanism. ${ }^{34 \mathrm{e}, \mathrm{f}}$

As shown in Table 1, cyclohexene conversion increased from 50\% to $63 \%$ when 2 was used as a catalyst instead of $\mathbf{1}$, and the former also has a higher turnover frequency (TOF) than the latter $\left(3740 \mathrm{~h}^{-1}\right.$ vs $\left.3100 \mathrm{~h}^{-1}\right)$. It appears that not only the total number and oxidation state of the manganese centers is important, but also the detailed structural arrangement of these metal ions in the polyanion structure. It should be remembered that the number of $\mathrm{Mn}^{3+}$ and $\mathrm{Mn}^{2+}$ ions is different in polyanions $\mathbf{1}$ and $\mathbf{2}$, and the latter also exhibits a small structural distortion (see Figure 2), compared to the more ideal tetrahedral situation for $\mathbf{1}$.

Battery performance. We decided to test the concept of NaCs-1 and NaRb-2 as anode materials in lithium ion battery (LIB) applications. The battery performances were investigated by galvanostatic charge-discharge (GCD) cycling and cyclic voltammetry (CV) in a half-cell configuration as described in the Experimental Section. CVs were measured for the first three cycles at a scan rate of $0.1 \mathrm{mV} \mathrm{s}^{-1}$ over a potential range of $0.01 \mathrm{~V}-2.0 \mathrm{~V} \mathrm{vs} . \mathrm{Li} / \mathrm{Li}^{+}$in order to 
understand the electrochemical properties of NaCs-1 and NaRb-2 electrodes as shown in Figure 7A and 7B. The NaCs-1 and NaRb-2 electrodes exhibited similar behavior in the CV curves. The solid electrolyte interphase (SEI) formed in the first cycle and generated an irreversible reduction peak at $\sim 0.7 \mathrm{~V}$ vs. $\mathrm{Li} / \mathrm{Li}^{+}$which disappeared in the following cycles. ${ }^{3 \mathrm{~d}}$ The main oxidation peaks can be observed at $1.07 \mathrm{~V}$ and $0.17 \mathrm{~V}$ vs. $\mathrm{Li} / \mathrm{Li}^{+}$, and the corresponding reduction peaks are located at $0.30 \mathrm{~V}$ and $0.01 \mathrm{~V}$ vs. $\mathrm{Li} / \mathrm{Li}^{+}$. These peaks might result from the redox transition of $\mathrm{Mn}$ and $\mathrm{W}$, and the insertion/extraction of Li ions with good reversibility. This can be further proved by X-ray photoelectron spectroscopy (XPS) and in-situ X-ray absorption spectroscopy (XAS) which are not discussed here.

The Figures 7C and 7D show the galvanostatic charge-discharge (GCD) curves of the NaCs-1 and NaRb-2 electrodes with initially 2 cycles at a current density of $100 \mathrm{~mA} \mathrm{~g}^{-1}$. Two well-defined plateaus can be observed on the discharge/charge curves where the potentials of the plateaus are similar to the redox peaks in the CV curves. The discharge capacity of the NaCs-1 and NaRb-2 electrodes in the first cycle are 908 and $727 \mathrm{mAh} \mathrm{g}^{-1}$, and the discharge capacities in the second cycle are 430 and $316 \mathrm{mAh} \mathrm{g}^{-1}$, respectively. These results are comparable with graphite (theoretical capacity: $372 \mathrm{mAh} \mathrm{g}^{-1}$ ) which is the most commonly used anode material in LIBs. ${ }^{35}$

The NaCs-1 and NaRb-2 electrodes exhibit high cycling stability with excellent coulombic efficiencies of $\sim 100 \%$ up to 50 cycles, see Figures $7 \mathrm{E}$ and $7 \mathrm{~F}$. The capacity retention for the NaCs1 electrode is $77 \%$ and for the NaRb-2 electrode is $85 \%$ (calculated using discharge capacity from $2^{\text {nd }}$ to $50^{\text {th }}$ cycle). The above results suggest that NaCs-1 and NaRb-2 electrodes are potentially interesting anode materials for real LIB applications. 

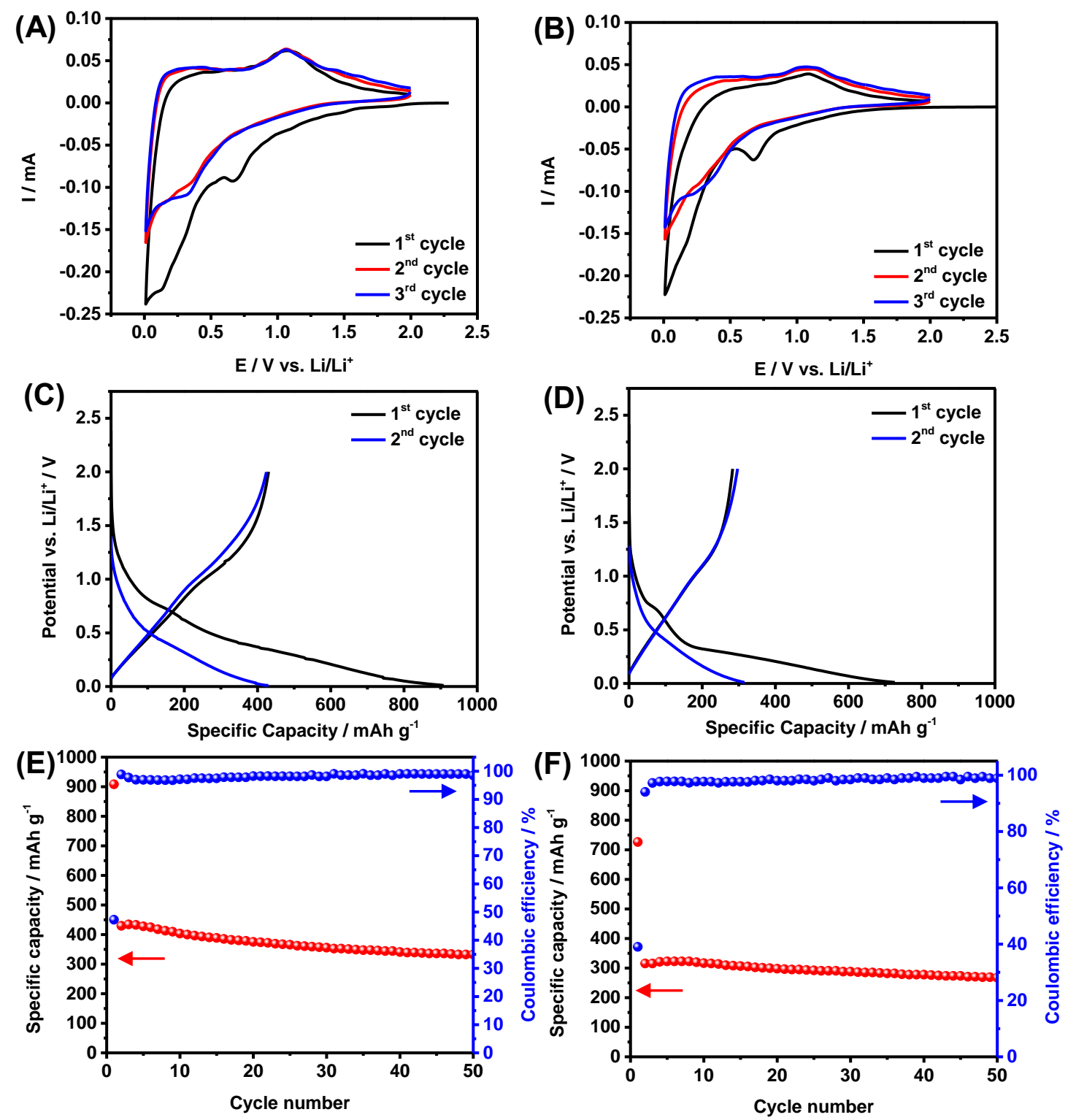

Figure 7. Battery performance of electrodes based on 1 and 2 in 1 M LiPF6/EC:DEC (1:1) in a half-cell configuration with Li metal as counter electrode: cyclic voltammograms of (a) NaCs-1 and (b) NaRb-2 electrodes measured at scan rate of $0.1 \mathrm{mV} \mathrm{s}-1$; the galvanostatic charge-discharge curves of (c) NaCs-1 and (d) NaRb-2 electrodes measured at current density of $100 \mathrm{~mA} \mathrm{~g}^{-1}$; the 
cycling performance and the coulombic efficiency of (e) NaCs-1 and (f) NaRb-2 electrodes measured at current density of $100 \mathrm{~mA} \mathrm{~g}^{-1}$.

\section{Conclusions}

We have successfully synthesized the two mixed-valent 16-manganese-containing 36-tungsto9-silicates $\left[\mathrm{Mn}^{\mathrm{III}}{ }_{10} \mathrm{Mn}_{6}{ }_{6} \mathrm{O}_{6}(\mathrm{OH})_{6}\left(\mathrm{PO}_{4}\right)_{4}\left(A-\alpha-\mathrm{SiW}_{9} \mathrm{O}_{34}\right)_{4}\right]^{28-}(\mathbf{1})$ and $\left[\mathrm{Mn}^{\mathrm{III}}{ }_{4} \mathrm{Mn}^{\mathrm{II}}{ }_{12}(\mathrm{OH})_{12}\left(\mathrm{PO}_{4}\right)_{4}(A\right.$ $\left.\left.\alpha-\mathrm{SiW}_{9} \mathrm{O}_{34}\right)_{4}\right]^{28-}(2)$ by careful tuning of the synthetic conditions. Synthesis of 1 with exclusively $\mathrm{Mn}^{3+}$ ions and synthesis of $\mathbf{2}$ with exclusively $\mathrm{Mn}^{2+}$ ions implies autoxidation and -reduction of manganese ions in situ. Interestingly, polyanions $\mathbf{1}$ and $\mathbf{2}$ comprise mixed-valent, cationic $\left\{\mathrm{Mn}^{\mathrm{III}}{ }_{10} \mathrm{Mn}_{6}{ }_{6} \mathrm{O}_{6}(\mathrm{OH})_{6}\right\}^{24+}$ and $\left\{\mathrm{Mn}^{\mathrm{III}}{ }_{4} \mathrm{Mn}_{12}{ }_{12}(\mathrm{OH})_{12}\right\}^{24+}$ cores, respectively, which have exactly the same charge. The hydrated mixed alkali salts of $\mathbf{1}$ and $\mathbf{2}$ were investigated in the solid state by single-crystal X-ray diffraction, FT-IR spectroscopy, thermogravimetric and elemental analyses, as well as X-ray absorption spectroscopy. Magnetic studies showed that polyanions $\mathbf{1}$ and $\mathbf{2}$ do not act as molecular magnets and possess a complex spin ground state which does not saturate even at 70000 Oe. Both 1 and 2 enhance the OER as shown by electrochemistry, and they also act as heterogeneous catalysts in the oxidation of cyclohexene. The difference in activity can be related to the different numbers of $\mathrm{Mn}^{3+}$ and $\mathrm{Mn}^{2+}$ ions and possibly a resulting subtle structural variation, and warrants further investigation. Furthermore, both $\mathbf{1}$ and $\mathbf{2}$ have been shown to act as potential anode candidates for LIBs with an initial discharge capacity of 908 and $727 \mathrm{mAh} \mathrm{g}^{-1}$, respectively, and excellent coulombic efficiencies $\sim 100 \%$ up to 50 cycles.

In summary, we have expanded the class of $\mathrm{M}_{16}$-containing tetrahedral polyanions to manganese with the discovery of two isostructural, mixed-valent $\mathrm{Mn}^{2+/ 3+}$ derivatives. Such compounds are structurally appealing, but more importantly, they contain a multitude of interesting electronic, redox, magnetic, and catalytic properties, which we have all explored. In future work we plan to 
investigate the catalytic properties of $\mathbf{1}$ and $\mathbf{2}$ in more detail, including water oxidation, and we will also try expanding this POM class further structurally and compositionally.

\section{ASSOCIATED CONTENT}

Supporting Information. X-ray crystallographic table, selected bond valence sum values, surface area measurements of the support and supported catalysts, IR spectra, TGA curves, additional magnetism figures, UV-vis spectra, and CIF files. This material is available free of charge via the Internet at http://pubs.acs.org.

\section{AUTHOR INFORMATION}

\section{Corresponding Author}

*E-mail: u.kortz@jacobs-university.de. Fax: (+49)421-200-3102. Homepage: www.jacobsuniversity.de/ses/ukortz

\section{Present Addresses}

${ }^{x}$ Current address: Institute of Nanotechnology, Karlsruhe Institute of Technology (KIT), Hermannvon-Helmholtz Platz 1, 76344 Eggenstein-Leopoldshafen, Germany.

+ Retired

\section{Author Contributions}

\# A.H. and M.I. contributed equally to this work. 


\section{ACKNOWLEDGMENT}

U. K. thanks the German Science Foundation (DFG, KO 2288/20-1), the CMST COST Action CM1203 (PoCheMoN), and Jacobs University for research support, and kindly acknowledges the Chinese Academy of Sciences President's International Fellowship Initiative (Grant No. 2015VMA041). A. H. thanks DAAD for a doctoral fellowship. M. I. thanks DFG and Institute of Nanotechnology, Karlsruhe Institute of Technology (KIT) for a postdoctoral fellowship, and she also thanks DAAD and the Higher Education Commission of Pakistan for a doctoral fellowship (Jacobs University). She also acknowledges the University of Balochistan, Quetta, Pakistan for allowing her to pursue $\mathrm{PhD}$ (Jacobs University) and postdoctoral (KIT) studies in Germany. The Advanced Light Source is supported by the Director, Office of Science, Office of Basic Energy Sciences, of the U.S. Department of Energy under Contract No. DE-AC02-05CH11231. G. J. Z thanks National Science Foundation of China (No. 21371173) for the funding and research support. H.-Y. C. and U. S. thank TUM CREATE, National Research Foundation of Singapore, and Newcastle University for research and funding support. Figures 1 and 2 were generated by Diamond, Version 3.2 (copyright Crystal Impact GbR). 


\section{REFERENCES}

1. a) Pope, M. T. Heteropoly and Isopoly Oxometalates, Springer, Berlin, 1983. b) Cronin, L. in Comprehensive Coordination Chemistry II, Vol .7 (Eds.: J. A. McCleverty, T. J. Meyer), Elsevier, Amsterdam, 2004, 1-56. (c) Pope, M. T.; Kortz, U. Polyoxometalates. Encyclopedia of Inorganic and Bioinorganic Chemistry; John Wiley \& Sons, Ltd.: Hoboken, NJ, 2012.

2. a) Pope, M. T.; Müller, A. Angew. Chem. Int. Ed. Engl. 1991, 30, 34-48. b) Hill, C. L.; Prosser-McCartha, C. M. Coord. Chem. Rev. 1995, 143, 407-455. c) Chem. Rev. 1998, 98, 1-390 (Special Issue on Polyoxometalates; Ed.: Hill, C. L.) d) Müller, A.; Roy, S. Coord. Chem. Rev. 2003, 245, 153-166. e) Hasenknopf, B.; Micoine, K.; Lacôte, E.; Thorimbert, S.; Malacria, M.; Thouvenot, R. Eur. J. Inorg. Chem. 2008, 5001-5013. f) Kortz, U.; Müller, A.; van Slageren, J.; Schnack, J.; Dalal, N. S.; Dressel, M. Coord. Chem. Rev. 2009, 253, 2315-2327. g) Eur. J. Inorg.

Chem. 2009, 34 (Issue dedicated to Polyoxometalates; Guest Ed. Kortz, U.) h) Long, D. L.; Tsunashima, R.; Cronin, L. Angew. Chem. Int. Ed. 2010, 49, 1736-1758. i) Izarova, N. V.; Pope, M. T.; Kortz, U. Angew. Chem. Int. Ed. 2012, 51, 9492-9510. j) Clemente-Juan, J. M.; Coronado, E.; Gaita-Ariño, A. Chem. Soc. Rev. 2012, 41, 7464-7478. k) Lv, H.; Geletii, Y. V.; Zhao, C.; Vickers, J. W.; Zhu, G.; Luo, Z.; Song, J.; Lian, T.; Musaev, D. G.; Hill, C. L. Chem. Soc. Rev. 2012, 41, 7572-7589.

3. a) Chen, H.-Y.; Al-Oweini, R.; Friedl, J.; Lee, C. Y.; Li, L.; Kortz, U.; Stimming, U.;

Srinivasan, M. Nanoscale 2015, 7, 7934-7941. b) Hartung, S.; Bucher, N.; Chen, H. -Y.; AlOweini, R.; Sreejith, S.; Borah, P.; Yanli, Z.; Kortz, U.; Stimming, U.; Hoster, H.; Srinivasan, M. J. Power Sources 2015, 288, 270-277. c) Chen, H. -Y.; Wee, G.; Al-Oweini, R.; Friedl, J.; Tan, K. S.; Wang, Y.; Wong, C. L.; Kortz, U.; Stimming, U.; Srinivasan, M. ChemPhysChem. 2014, 
15, 2162-2169. d) Ma, D.; Liang, L.; Chen, W.; Liu, H.; Song, Y. -F.; Adv. Funct. Mater. 2013, $23,6100-6105$.

4. a) Chem. Soc. Rev. 2012, 41, $7325-7648$ (Special Issue on Polyoxometalates; Ed.: Cronin, L.; Müller, A.). b) Zheng, S. T.; Yang, G. Y. Chem. Soc. Rev. 2012, 41, 7623-7646. c) Oms, O.; Dolbecq, A.; Mialane, P. Chem. Soc. Rev. 2012, 41, 7497-7536.

5. a) Lyon, D. K.; Miller, W. K.; Novet, T.; Domaille, P. J.; Evitt, E.; Johnson, D. C.; Finke, R. G. J. Am. Chem. Soc. 1991, 113, 7209-7221. b) Cowan, J. J.; Bailey, A. J.; Heintz, R. A.; Do, B. T.; Hardeastle, K. I.; Hill, C. L.; Weinstock, I. A. Inorg. Chem. 2001, 40, 6666-6675. c) Bassil, B. S.; Dickman, M. H.; Reicke, M.; Kortz, U.; Keita, B.; Nadjo, L. Dalton Trans. 2006, 42534259. d) Zhang, D.; Zhang, Y.; Zhao, J.; Ma, P.; Wang, J.; Niu, J. Eur. J. Inorg. Chem. 2013, 16721680. e) Sato, R.; Suzuki, K.; Minato, T.; Shinoe, M.; Yamaguchi, K.; Mizuno, N. Chem. Commun. 2015, 51, 4081-4084.

6. a) Zhang, X. Y.; O’Connor, C. J.; Jameson, G. B.; Pope, M. T. Inorg. Chem. 1996, 35, 3034. b) Kortz, U.; Al-Kassem, N. K.; Savelieff, M. G.; Al Kadi, N. A.; Sadakane, M. Inorg. Chem. 2001, 40, 4742-4749. c) Zhang, Z. M.; Yao, S.; Li, Y. G.; Wang, Y. H.; Qi, Y. F.; Wang, E. B. Chem. Commun. 2008, 1650-1652. d) Hou, Y.; Xu, L.; Cichon, M. J.; Lense, S.; Hardcastle, K. I.; Hill, C. L. Inorg. Chem. 2010, 49, 4125-4132. e) Car, P. E.; Spingler, B.; Weyeneth, S.; Patscheider, J.; Patzke, G. R. Polyhedron 2013, 52, 151-158. f) Jiao, Y. Q.; Qin, C.; Wang, X. L.; Liu, F. H.; Huang, P.; Wang, C. G.; Shao, K. Z.; Su, Z. M. Chem. Commun. 2014, 50, 5961-5963. g) Winter, R. S.; Long, D. L.; Cronin, L. Inorg. Chem. 2015, 54, 4151-4155.

7. a) Liu, J. G.; Ortéga, F.; Sethuraman, P.; Katsoulis, D. E.; Costello, C. E.; Pope, M. T. J. Chem. Soc., Dalton Trans. 1992, 1901-1906. b) Kortz, U.; Matta, S. Inorg. Chem. 2001, 40, 815817. c) Mialane, P.; Marrot, J.; Riviére, E.; Nebout, J. Hervé, G. Inorg. Chem. 2001, 40, 44-48. d) 
Dutta, D.; Jana, A. D.; Debnath, M.; Mostafa, G.; Clérac, R.; Tojal, J. G.; Ali, M.; Eur. J. Inorg. Chem. 2010, 2010, 5517-5522. e) Al-Oweini, R.; Bassil, B. S.; Palden, T.; Keita, B.; Lan, Y.; Powell, A. K.; Kortz, U. Polyhedron 2013, 52, 461-466. f) Shevchenko, D.; Huang, P.; Bon, V. V.; Anderlund, M. F.; Kokozay, V. N.; Styring, S.; Thapper, A. Dalton Trans. 2013, 42, 51305139. g) Al-Oweini, R.; Bassil, B. S.; Friedl, J.; Kottisch, V. ; Ibrahim, M.; Asano, M.; Keita, B.; Novitchi, G.; Lan, Y.; Powell, A. K.; Stimming, U.; Kortz, U. Inorg. Chem. 2014, 53, 5663-5673.

8. a) Gomez-Garcia, C. J.; Coronado, E.; Gomez-Romero, P.; Casan-Pastor, N.; Inorg. Chem. 1993, 32, 3378-3381. b) Gomez-Garcia, C. J.; Borras-Almenar, J. J. ; Coronado, E. ; Ouahab, L. Inorg. Chem. 1994, 33, 4016-4022. c) Zhang, X. Y.; Jameson, G. B.; O’ Connor, C. J.; Pope, M. T. Polyhedron 1996, 15, 917-922. d) Bi, L. H.; Wang, E. B.; Peng, J.; Huang, R. D.; Xu, L.; Hu, C.W. Inorg. Chem., 2000, 39, 671-679. e) Kortz, U. Isber, S. Dickman, M. H.; Ravot, D. Inorg. Chem. 2000, 39, 2915-2922. f) Kortz, U.; Nellutla, S.; Stowe, A. C.; Dalal, N. S.; Rauwald, U.; Danquah, W.; Ravot, D. Inorg. Chem. 2004, 43, 2308-2317. g) Mialane, P.; Duboc, C.; Marrot, J.; Rivière, E.; Dolbecq, A.; Sécheresse, F. Chem. Eur. J. 2006, 12, 1950-1959. h) Fang, X. K.; Speldrich, M.; Schilder, H.; Cao, R.; O’ Halloran, K. P.; Hill, C. L.; Kögerler, P. Chem. Commun. 2010, 46, 2760-2765. i) Bassil, B. S.; Ibrahim, M.; Mal, S. S.; Suchopar, A.; Biboum, R. N.; Keita, B.; Nadjo, L.; Nellutla, S.; van Tol, J.; Dalal, N. S. Kortz, U. Inorg. Chem. 2010, 49, 4949-4959. j) Yao, S.; Yan, J.; Yu. Y.; Wang, E. J. Coord. Chem. 2012, 65, 1451-1458. k) Fang, X.; McCallum, K.; Pratt III, H. D.; Anderson, T. M.; Dennis, K. Luban, M. Dalton Trans. 2012, 41, 9867-9870.

9. Suzuki, K.; Sato, R.; Minato, T.; Shinoe, M.; Yamaguchi, K.; Mizuno, N. Dalton Trans. 2015, 44, 14220-14226. 
10. a) Ritorto, M. D.; Anderson, T. M.; Neiwert, W. A.; Hill, C. L. Inorg. Chem. 2004, 43, 4449. b) Ritchie, C.; Ferguson, A.; Nojiri, H.; Miras, H. N.; Song, Y. F.; Long, D. L.; Burkholder, E.; Murrie, M.; Kögerler, P.; Brechin, E. K.; Cronin, L. Angew. Chem., Int. Ed. 2008, 47, 56095612. c) Mitchell, S. G.; Khanra, S.; Miras, H. N.; Boyd, T.; Long, D. L.; Cronin, L. Chem. Commun. 2009, 2712-2714. d) Jiang, N.; Li, F. Y.; Xu, L.; Li, Y. G. ; Li, J. M. Inorg. Chem. Commun. 2010, 13, 372-375. e) Mitchell, S. G.; Molina, P. I.; Khanra, S.; Miras, H. N.; Prescimone, A.; Cooper, G. J. T.; Winter, R. S.; Brechin, E. K.; Long, D. L.; Cogdell, R. J.; Cronin, L. Angew. Chem., Int. Ed. 2011, 50, 9154-9157. f) Yang, L.; Liu, Q.; Ma, P.; Niu, J.; Wang, J. Dalton Trans. 2015, 44, 13469-13472.

11. a) Nsouli, N. H.; Ismail, A. H.; Helgadottir, I. S.; Dickman, M. H.; Clemente-Juan, J. M.; Kortz, U. Inorg. Chem. 2009, 48, 5884-5890. b) Chen, L. J.; Shi, D. Y.; Zhao, J. W.; Wang, Y. L.; Ma, P. T.; Wang, J. P.; Niu, J. Y. Cryst. Growth Des. 2011, 11, 1913-1923. c) Fang, X. K.; Kögerler, P.; Speldrich, M.; Schilder, H.; Luban, M. Chem. Commun. 2012, 48, 1218-1220 d) Winter, R. S.; Yan, J.; Busche, C.; Mathieson, J. S.; Prescimone, A.; Brechin, E. K.; Long, D. L.; Cronin, L. Chem. Eur. J., 2013, 19, 2976-2981.

12. a) Huang, L.; Cheng, L.; Fang, W. H.; Wang, S. S.; Yang, G. Y. Eur. J. Inorg. Chem., 2013, 1693-1698. b) Molina, P. I.; Miras, H. N.; Long, D. L.; Cronin, L. Inorg. Chem., 2013, 52, 9284-9289.

13. Mitchell, S. G.; Miras, H. N.; Long, D. L.; Cronin, L. Inorg. Chim. Acta. 2010, 363, 42404246.

14. Zhang, Z. M.; Yao, S.; Li, Y. G.; Wu, H. H.; Wang, Y. H.; Rouzières, M.; Clérac, R.; Su, Z. M.; Wang, E. B. Chem. Commun., 2013, 49, 2515-2517. 
15. a) Wu, Q.; Li, Y. G.; Wang, Y. H.; Wang, E. B.; Zhang, Z. M.; Clérac, R. Inorg. Chem. 2009, 48, 1606-1612. b) Fang, X. K.; Luban, M. Chem. Commun. 2011, 47, 3066-3068.

16. Bassil, B. S.; Ibrahim, M.; Al-Oweini, R.; Asano, M.; Wang, Z. X.; van Tol, J.; Dalal, N. S.; Choi, K. Y.; Biboum, R. N.; Keita, B.; Nadjo, L.; Kortz, U. Angew. Chem., Int. Ed. 2011, 50, 5961-5964.

17. Fang, X.; Kögerler, P.; Furukawa, Y.; Speldrich, M.; Luban, M. Angew. Chem., Int. Ed. 2011, 50, 5212-5216.

18. a) Mbomekalle, I. M.; Keita, B.; Nierlich, M.; Kortz, U.; Berthet, P.; Nadjo, L. Inorg. Chem. 2003, 42, 5143-5152. b) Mbomekalle, I. M.; Keita, B.; Nadjo, L.; Neiwert, W. A.; Zhang, L.; Hardcastle, K. I.; Hill, C. L.; Anderson, T. M. Eur. J. Inorg. Chem. 2003, 3924-3928. c) Keita, B.; Mbomekallé, I. M.; Nadjo, L.; Anderson, T. M.; Hill, C. L. Inorg. Chem. 2004, 43, 3257-3263. d) Ruhlmann, L.; Costa-Coquelard, C.; Canny, J.; Thouvenot, R. Eur. J. Inorg. Chem., 2007, 14931500. e) Fang, X. F.; Kögerler, P. Angew. Chem., Int. Ed. 2008, 47, 8123-8126. f) Fang, X. K.; Kögerler, P. Chem. Commun. 2008, 3396-3398. g) Reinoso, S.; Gálán-Mascarós, J. R. Inorg. Chem., 2010, 49, 377-379.

19. Al-Oweini, R.; Sartorel, A.; Bassil, B. S.; Natali, M.; Berardi, S.; Scandola, F.; Kortz, U.; Bonchio, M. Angew. Chem. Int. Ed. 2014, 53, 11182-11185.

20. a) Ibrahim, M.; Lan, Y.; Bassil, B. S.; Xiang, Y.; Suchopar, A.; Powell, A. K.; Kortz, U. Angew. Chem. Int. Ed. 2011, 50, 4708-4711. b) Ibrahim, M.; Haider, A.; Lan, Y.; Bassil, B. S.; Carey, A. M.; Liu, R.; Zhang, G.; Keita, B.; Li, W.; Kostakis, G. E.; Powell, A. K.; Kortz, U. Inorg. Chem. 2014, 53, 263-266.

21. Han, X. B.; Zhang, Z. M.; Zhang, T.; Li, Y. G.; Lin, W.; You, W.; Su, Z. M.; Wang, E. B. J. Am. Chem. Soc., 2014, 136, 5359-5366. 
22. Ibrahim, M.; Haider, A.; Xiang, Y.; Bassil, B. S.; Carey, A. M.; Rullik, L.; Jameson, G. B.; Doungmene, F.; Mbomekallé, I. M.; de Oliveira, P.; Mereacre, V.; Kostakis, G. E.; Powell, A. K.; Kortz, U. Inorg. Chem. 2015, 54, 6136-6146.

23. Hervé, G.; Tézé, A. Inorg. Chem. 1977, 16, 2115-2117.

24. SAINT; Bruker AXS Inc.: Madison, WI, 2007.

25. a) Sheldrick, G. M. Acta Crystallogr. A. 2007, 64, 112-122. b) Sheldrick, G. M. SADABS; University of Göttingen, Göttingen, Germany, 1996.

26. Sheldrick, G. M. SHELX-97/2013, Program for Solution of Crystal Structures; University of Göttingen: Göttingen, Germany, 1997, 2013.

27. Brown, I. D.; Altermatt, D. Acta Crystallogr. Sect. B 1985, 41, 244-247.

28. a) Clemente-Juan, J. M.; Coronado, E.; Galán-Mascarós, J. R.; Gómez-García, C. J. Inorg. Chem. 1999, 38, 55-63. b) Zhao, J. W.; Jia, H. P.; Zhang, J.; Zheng, S. T.; Yang, G. Y. Chem. Eur. J., 2007, 13, 10030-10045. c) Pichon, C.; Dolbecq, A.; Mialane, P.; Marrot, J.; Riviére, E.; Sécheresse, F. Dalton Trans., 2008, 1, 71-76. d) Lydon, C.; Sabi, M. M.; Symes, M. D.; Long, D. L.; Murrie, M.; Yoshii, S.; Nojiri, H.; Cronin, L. Chem. Commun. 2012, 48, 9819-9821. e) Ibrahim, M. Xiang, Y.; Bassil, B. S.; Lan, Y.; Powell, A. K.; de Oliveira, P.; Keita, B.; Kortz, U. Inorg. Chem. 2013, 52, 8399-8408.

29. Khanra, S.; Kuepper, K.; Weyermüller, T.; Prinz, M.; Raekers, M.; Voget, S.; Postnikov, A. V.; De Groot, F. M. F.; George, S. J.; Coldea, M.; Neumann, M.; Chaudhuri, P. Inorg. Chem. 2008, 47, 4605-4617.

30. Prinz, M.; Raekers, M.; Neumann, M.; Kuepper, K.; Khanra, S.; Weyhermüller, T.; Chaudhuri, P. Z. Phys. Chem. 2009, 223, 145-155. 
31. a) Liu, J. G.; Ortéga, F.; Sethuraman, P.; Katsoulis, D. E.; Costello, C. E.; Pope, M. T. J. Chem. Soc., Dalton Trans. 1992, 1901-1906. b) Zhang, X. Y.; Pope, M. T.; Chance, M. R.; Jameson, G. B. Polyhedron 1995, 14, 1381-1392. c) Sadakane, M.; Steckhan, E. Acta Chem. Scand. 1999, 53, 837-841. d) Sadakane, M.; Steckhan, E. J. Mol. Catal. Chem. 1996, 114, 221228. e) Keita, B.; Mialane, P.; Sécheresse, F.; de Oliveira, P.; Nadjo, L. Electrochem. Commun. 2007, 9, 164-172. f) Friedl, J.; Al-Oweini, R.; Herpich, M.; Keita, B.; Kortz, U.; Stimming, U. Electrochim. Acta. 2014, 141, 357-366.

32. a) Keita, B.; Nadjo, L. Electrochemistry of Isopoly and Heteropoly Oxometalates. In Encyclopedia of Electrochemistry; Bard, A. J. and Stratmann, M. Eds. Wiley-VCH: Weinheim, Germany, 2006; Vol. 7, pp 607. b) Lopez, I. X.; Carbo, J. J.; Bo, C.; Poblet, J. M. Chem. Soc. Rev. 2012, 41, 7537-7571.

33. a) Chen, L.; Zhu, K.; Bi, L.H.; Suchopar, A.; Reicke, M.; Mathys, G.; Jaensch, H.; Kortz, U.; Richards, R. M. Inorg. Chem. 2007, 46, 8457-8459. b) Chen, L.; Hu, J.; Mal, S. S.; Kortz, U.; Jaensch, H.; Mathys, G.; Richards, R. M. Chem. Eur. J. 2009, 15, 7490-7497. c) Bi, L.-H.; AlKadamany, G.; Chubarova, E. V.; Dickman, M. H.; Chen, L.; Gopala, D. S.; Richards, R. M.; Keita, B.; Nadjo, L.; Jaensch, H.; Mathys, G.; Kortz, U. Inorg. Chem. 2009, 48, 10068-10077.

34. a) Hill, C. L.; Brown, R. B. J. Am. Chem. Soc. 1986, 108, 536-538. b) Mansuy, D.; Bartoli, J. -F.; Battioni, P.; Lyon, D. K.; Frinke, R. G. J. Am. Chem. Soc. 1991, 113, 7222-7226. c) Qin, D.; Wang, G.; Wu, Y. Stud. Surf. Sci. Catal. 1994, 82, 603-608. d) Guo, J.; Jiao, Q. Z.; Shen, J. P.; Jiang, D. Z.; Yang, G. H.; Min, E. Z. Catal. Lett. 1996, 40, 43-45. e) Kholdeeva, O. A.; Donoeva, B. G.; Trubitsina, T. A.; Al-Kadamany, G.; Kortz, U. Eur. J. Inorg. Chem. 2009 5134-5141. f) Hussain, F.; Bassil, B. S.; Kortz, U.; Kholdeeva, O. A.; Timofeeva, M. N.; de Oliveira, P.; Keita, B.; Nadjo, L.; Chem. Eur. J., 2007, 13, 4733-4742. g) Timofeeva, N.; Kholdeeva, O. A.; Jhung, S. 
H.; Chang, J. S. Appl. Catal. A. 2008, 345, 195-200. h) Kumar, A.; Srinivas, D.; Ratnasamy, P. Chem. Commun. 2009, 6484-6486. i) Kholdeeva, O. A.; Derevyankin, A. Yu.; Shmakov, A. N.; Trukhan, E. A. N. N.; Paukshtis, A.; Tuel, V. N.; Romannikov, J. Mol. Catal. A: Chem. 2000, 158, 417-421.

35. Kovalenko, I.; Zdyrko, B.; Magasinski, A.; Hertzberg, B.; Milicev, Z.; Burtovyy, R.; Luzinov, I.; Yushin, G. Science, 2011, 334, 75-79. 
SYNOPSIS. The two mixed-valent, 16-manganese-containing, Keggin-based 36-tungsto-9silicates $\left[\mathrm{Mn}^{\mathrm{III}}{ }_{10} \mathrm{Mn}_{6}{ }_{6} \mathrm{O}_{6}(\mathrm{OH})_{6}\left(\mathrm{PO}_{4}\right)_{4}\left(A-\alpha-\mathrm{SiW}_{9} \mathrm{O}_{34}\right)_{4}\right]^{28-}(\mathbf{1})$ and $\left[\mathrm{Mn}^{\mathrm{III}}{ }_{4} \mathrm{Mn}^{\mathrm{II}}{ }_{12}(\mathrm{OH})_{12}\left(\mathrm{PO}_{4}\right)_{4}(A-\alpha-\right.$ $\left.\left.\mathrm{SiW}_{9} \mathrm{O}_{34}\right)_{4}\right]^{28-}(2)$ have been discovered and structurally characterized, and analyzed in the areas of electrochemistry and -catalysis, magnetism, heterogeneous oxidation catalysis, and Li-ion batteries.

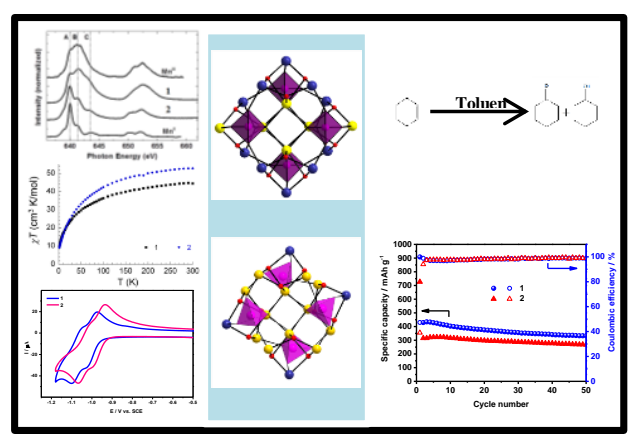


Supplement 


\section{Single Crystal X-Ray Crystallography}

Table S1. Crystal data for NaCs-1 and NaRb-2.

\begin{tabular}{|c|c|c|}
\hline Compound & NaCs-1 & NaRb-2 \\
\hline Empirical formula & $\mathrm{Cs}_{8.5} \mathrm{H}_{186} \mathrm{Mn}_{16} \mathrm{Na}_{19.5} \mathrm{O}_{254} \mathrm{P}_{4} \mathrm{Si}_{4} \mathrm{~W}_{36}$ & $\mathrm{H}_{162} \mathrm{Mn}_{16} \mathrm{Na}_{18} \mathrm{O}_{239} \mathrm{P}_{4} \mathrm{Rb}_{10} \mathrm{Si}_{4} \mathrm{~W}_{36}$ \\
\hline Formula weight, g/mol & 13563.40 & 12989.69 \\
\hline Crystal system & Orthorhombic & Monoclinic \\
\hline Space group & Pmmn (59) & $C 2 / c(15)$ \\
\hline$a, \AA$ & $22.8196(11)$ & $30.396(5)$ \\
\hline$b, \AA$ & $27.8094(14)$ & $34.763(6)$ \\
\hline$c, \AA$ & $18.9335(11)$ & $21.649(4)$ \\
\hline$\alpha,{ }^{\circ}$ & 90.00 & 90.00 \\
\hline$\beta$, ${ }^{\circ}$ & 90.00 & $99.069(9)$ \\
\hline$\gamma,{ }^{\circ}$ & 90.00 & 90.00 \\
\hline Volume, $\AA^{3}$ & $12015.2(11)$ & $22589(7)$ \\
\hline $\mathrm{Z}$ & 2 & 4 \\
\hline$D_{\text {calc }}, \mathrm{g} / \mathrm{cm}^{3}$ & 3.749 & 3.820 \\
\hline Absorption coefficient & 19.438 & 21.457 \\
\hline $\mathrm{F}(000)$ & 12160 & 23288 \\
\hline Crystal size, $\mathrm{mm}^{3}$ & $0.2 \times 0.1 \times 0.1$ & $0.3 \times 0.3 \times 0.1$ \\
\hline $\begin{array}{l}\text { Theta range for data } \\
\text { collection, }\end{array}$ & $3.428-29.574$ & $3.428-26.373$ \\
\hline Reflections collected & 665187 & 438741 \\
\hline Independent reflections & 17561 & 23032 \\
\hline R(int) & 0.0990 & 0.1503 \\
\hline Observed $(\mathrm{I}>2 \sigma(\mathrm{I}))$ & 14492 & 17556 \\
\hline Goodness-of-fit on F2 & 1.008 & 1.000 \\
\hline $\mathrm{R}_{1}[\mathrm{I}>2 \sigma(\mathrm{I})]^{[\mathrm{a}]}$ & 0.0460 & 0.0692 \\
\hline $\mathrm{wR}_{2}{\text { (all data })^{[\mathrm{b}]}}$ & 0.1383 & 0.1794 \\
\hline
\end{tabular}




\section{Bond Valance Sum Calculations}

Table S2. Selected bond valence sum (BVS) values for $\mathbf{1}$ (upper) and $\mathbf{2}$ (lower).

$\left[\mathrm{Mn}_{6}{ }_{6} \mathrm{Mn}^{\mathrm{III}}{ }_{10} \mathrm{O}_{6}(\mathrm{OH})_{6}\left(\mathrm{PO}_{4}\right)_{4}\left(A-\alpha-\mathrm{SiW}_{9} \mathrm{O}_{34}\right)_{4}\right]^{28-}(1)$

\begin{tabular}{|c|c|c|c|}
\hline$\mu_{3}-\mathrm{O}(3 \mathrm{Mn}-\mathrm{O})$ & BVS Value & Mn & BVS value \\
\hline $\mathrm{O} 45 \mathrm{M}$ & 1.47 & Mn1 & 1.60 \\
\hline $\mathrm{O} 25 \mathrm{M}$ & 1.56 & $\mathrm{Mn} 2$ & 1.67 \\
\hline $\mathrm{O} 36 \mathrm{M}$ & 1.46 & Mn3 & 2.82 \\
\hline O13M & 1.48 & $\mathrm{Mn} 4$ & 2.20 \\
\hline$\mu_{2}-\mathrm{O}(\mathrm{Mn}-\mathrm{O}-\mathrm{P})$ & & Mn5 & 3.20 \\
\hline O1P2 & 1.82 & Mn6 & 3.20 \\
\hline $\mathrm{O} 2 \mathrm{P} 1$ & 1.81 & $\mathbf{P}$ & \\
\hline $\mathrm{O} 2 \mathrm{P} 2$ & 1.83 & P1 & 5.15 \\
\hline O3P1 & 1.76 & $\mathrm{P} 2$ & 5.28 \\
\hline \multicolumn{2}{|l|}{$\mu_{4}-\mathrm{O}(3 \mathrm{Mn}-\mathrm{O}-\mathrm{P})$} & & \\
\hline O1P1 & 2.07 & & \\
\hline O3P2 & 2.04 & & \\
\hline
\end{tabular}

$\left[\left\{\mathrm{Mn}_{3}{ }_{3} \mathrm{Mn}^{\mathrm{III}}(\mathrm{OH})_{3} \mathrm{PO}_{4}\right\}_{4}\left(A-\alpha-\mathrm{SiW}_{9} \mathrm{O}_{34}\right)_{4}\right]^{28-}(2)$

\begin{tabular}{|l|l|l|l|}
\hline $\boldsymbol{\mu 3}$-O (3Mn-O) & BVS Value & Mn & BVS value \\
\hline O34M & 1.18 & Mn1 & 2.77 \\
\hline O34N & 1.24 & Mn2 & 2.31 \\
\hline O24M & 1.25 & Mn3 & 2.30 \\
\hline O78N & 1.14 & Mn4 & 1.84 \\
\hline O69M & 1.26 & Mn5 & 3.14 \\
\hline O78M & 1.27 & Mn6 & 2.32 \\
\hline
\end{tabular}




\begin{tabular}{|c|c|c|c|}
\hline & & $\mathrm{Mn} 7$ & 2.15 \\
\hline & & Mn8 & 1.82 \\
\hline$\mu_{2}-\mathrm{O}(\mathrm{Mn}-\mathrm{O}-\mathrm{P})$ & & $\mathbf{P}$ & \\
\hline $\mathrm{O} 2 \mathrm{P} 1$ & 1.64 & P1 & 5.06 \\
\hline $\mathrm{O} 2 \mathrm{P} 2$ & 1.75 & P2 & 5.03 \\
\hline O4P2 & 1.75 & & \\
\hline O3P1 & 1.76 & & \\
\hline O4P1 & 1.72 & & \\
\hline O1P2 & 1.65 & & \\
\hline$\mu_{4-O}(3 \mathrm{Mn}-\mathrm{O}-\mathrm{P})$ & & & \\
\hline O1P1 & 2.08 & & \\
\hline O3P2 & 2.07 & & \\
\hline
\end{tabular}

\section{Surface Area Measurements of Support and Supported POM Catalyst.}

The measurements were recorded using a NOVA-4000e instrument. The samples were degassed at $150{ }^{\circ} \mathrm{C}$ under vacuum for $24 \mathrm{~h}$ prior to the measurement. The specific surface areas were evaluated with the Brunauer-Emmett-Teller (BET) method in the $\mathrm{P} / \mathrm{P}_{0}$ range of 0.05-0.35.

Table S3. Composition and specific surface area of the support and the supported POM catalyst.

\begin{tabular}{|c|c|}
\hline Sample & Surface Area BET $\left(\mathbf{m}^{2} / \mathbf{g}\right)$ \\
\hline SBA-15 & 800 \\
\hline SBA-15-apts & 500 \\
\hline SBA-15-apts-1 & 360 \\
\hline SBA-15-apts-2 & 350 \\
\hline
\end{tabular}




\section{Supplementary Figures}

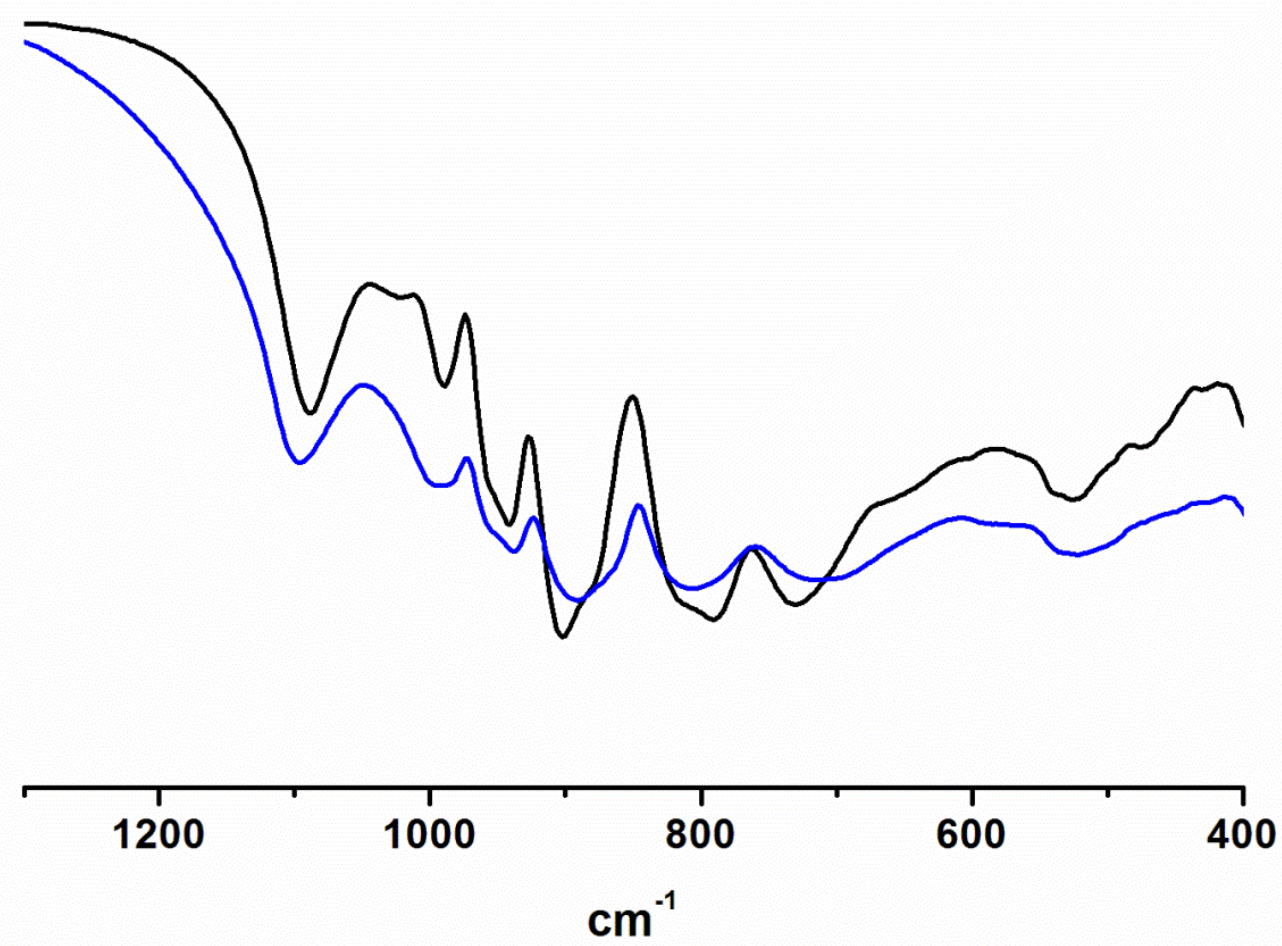

Figure S1. Infrared spectra of NaCs-1 (black) and NaRb-2 (blue) showing only the POM fingerprint region. 


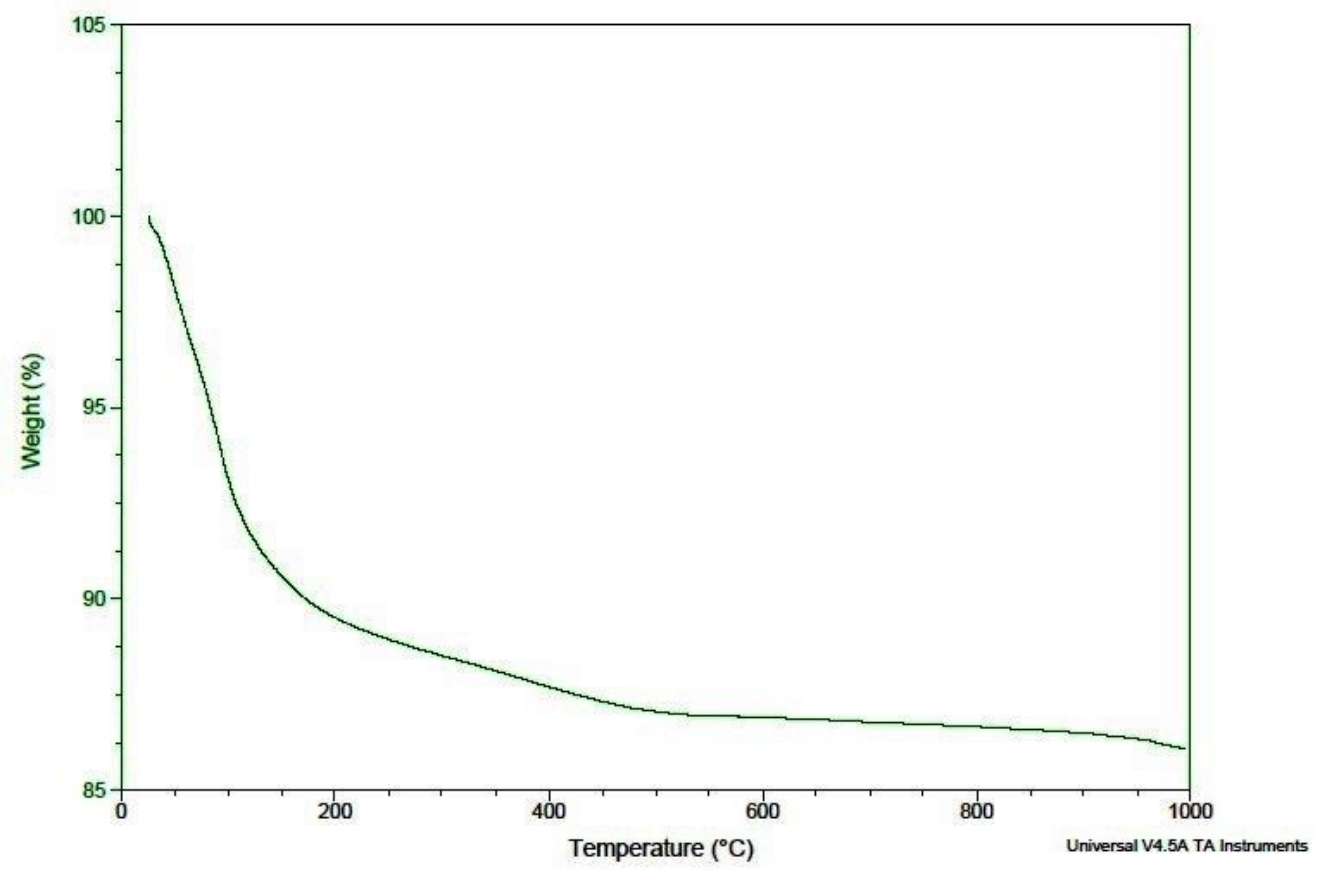

Figure S2. Thermogram of NaCs-1 from room temperature to $1000{ }^{\circ} \mathrm{C}$.

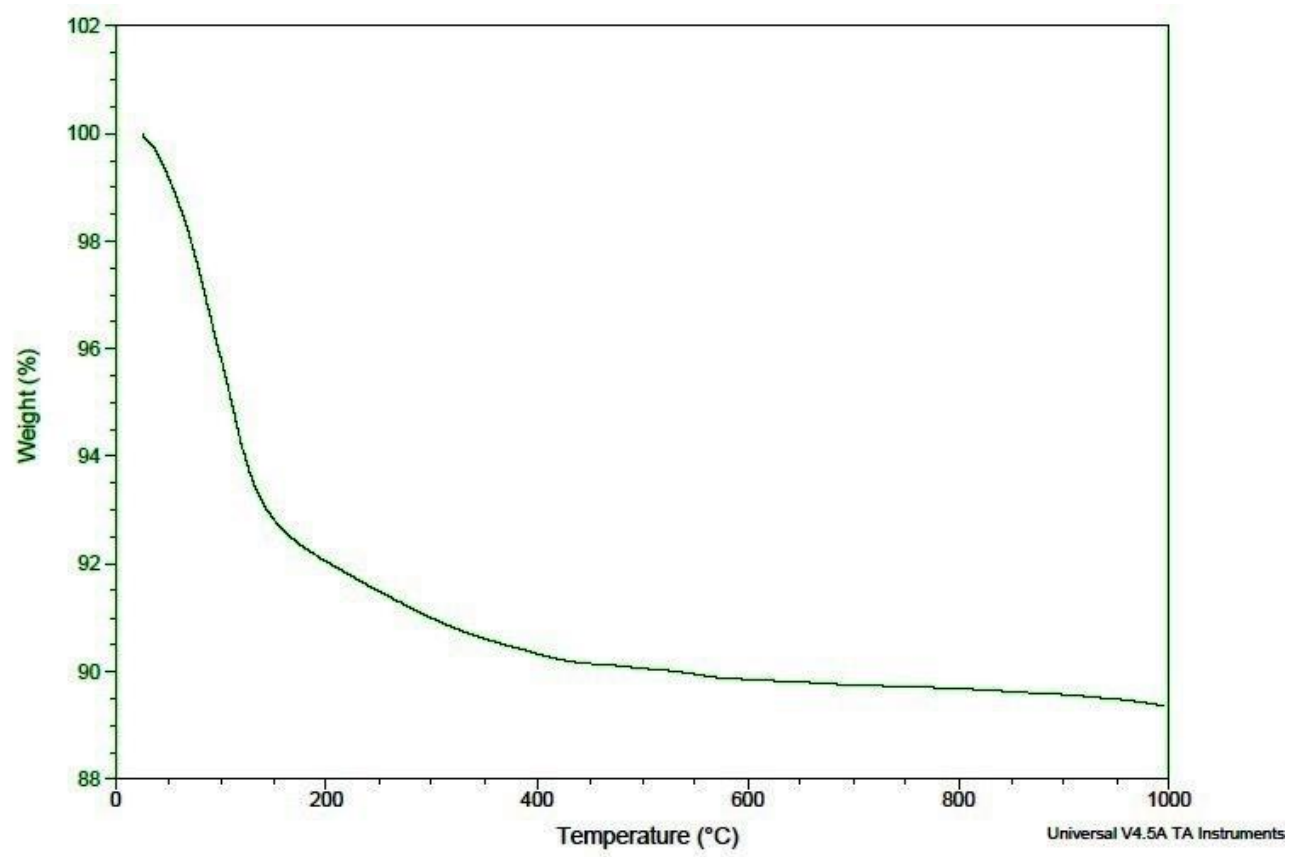

Figure S3. Thermogram of NaRb-2 from room temperature to $1000{ }^{\circ} \mathrm{C}$. 

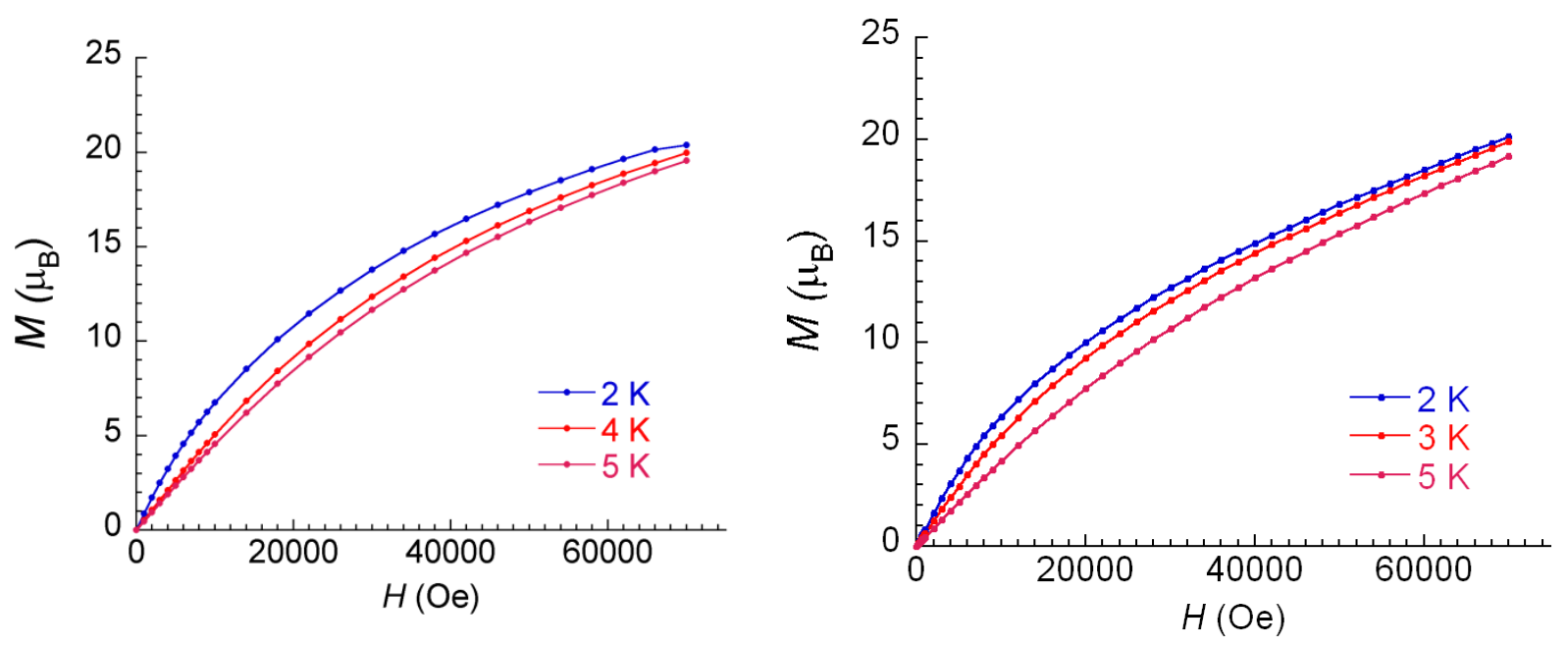

Figure S4. Field dependence of the magnetization for $\mathbf{1}$ (left) and $\mathbf{2}$ (right) at 2, 3, and $5 \mathrm{~K}$.
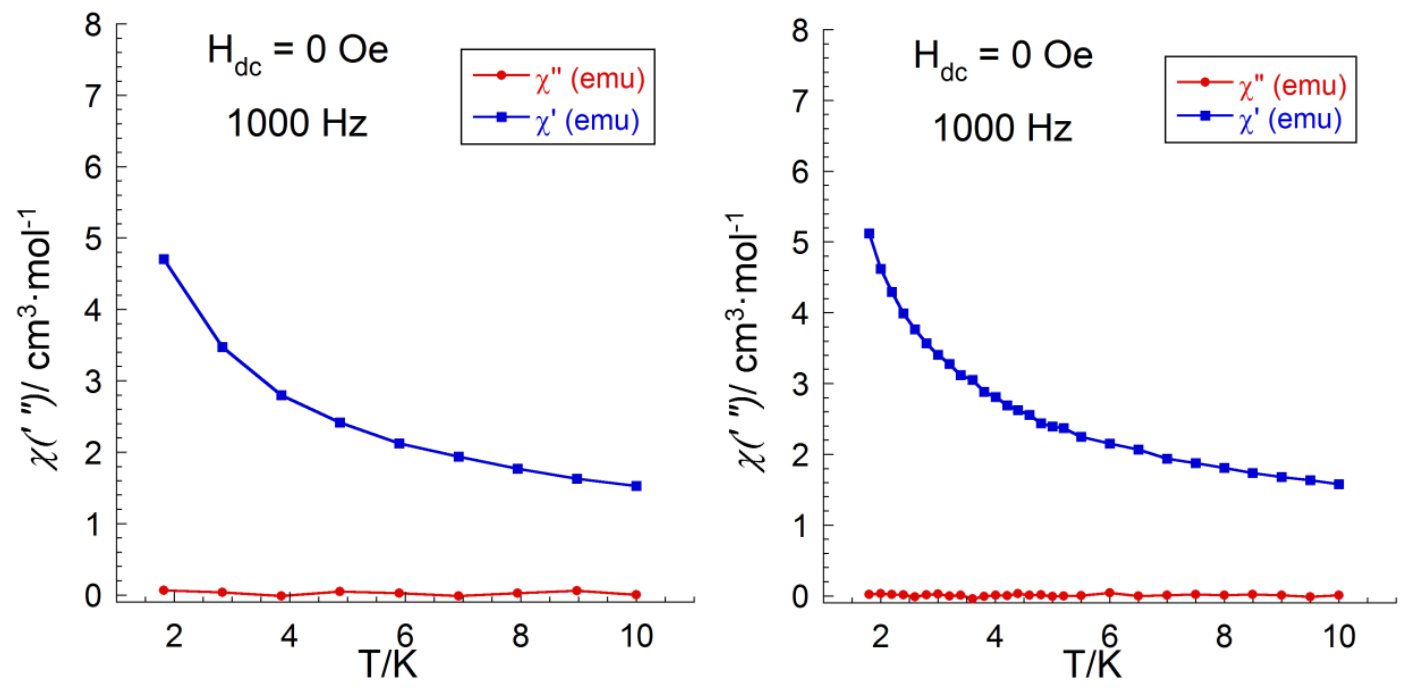

Figure S5. Temperature dependence of the in-phase and out-of-phase components of the ac magnetic susceptibility at $1000 \mathrm{~Hz}$ for $\mathbf{1}$ (left) and $\mathbf{2}$ (right) at 0 Oe. 

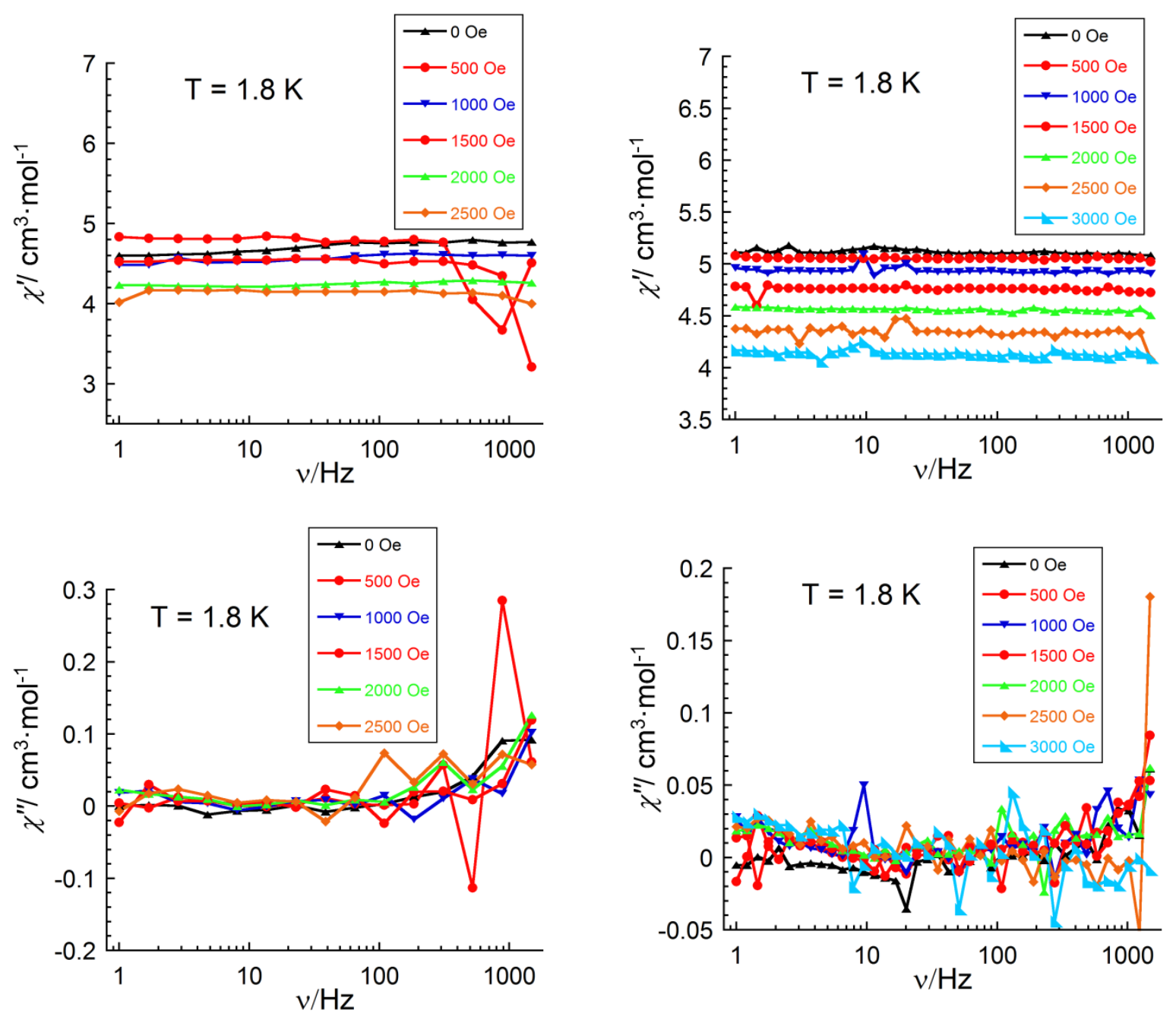

Figure S6. Frequency dependence of the out-of-phase ac susceptibility component for 1 (left) and 2 (right) at $1.8 \mathrm{~K}$ under different dc fields (0-3000 Oe). 


\section{UV-vis absorption spectroscopy}

Spectra were recorded with a Shimazu U2550 spectrophotometer. In the UV region, the spectra of both polyanions $\mathbf{1}$ and $\mathbf{2}$ exhibit intense absorption bands attributed to oxygen-to-tungsten charge transfer transition. In the UV region, the spectra exhibit intense absorption bands at around 250 nm for $\mathbf{1}$ and $\mathbf{2}$. These absorption bands are due to oxygen-to-tungsten charge transfer transitions. The spectrum of the Mn centers present a well-defined band located at $434.5 \mathrm{~nm}$ and $429.5 \mathrm{~nm}$ for 1 and 2, respectively. Both spectra present also shoulders at around $540 \mathrm{~nm}$ and $400 \mathrm{~nm}$. Figure S5 features the $\mathrm{W}$ and Mn centers absorption spectra for $\mathbf{1}$. For the stability tests, UV/vis spectra of POM-containing solutions recorded as a function of time were compared. 

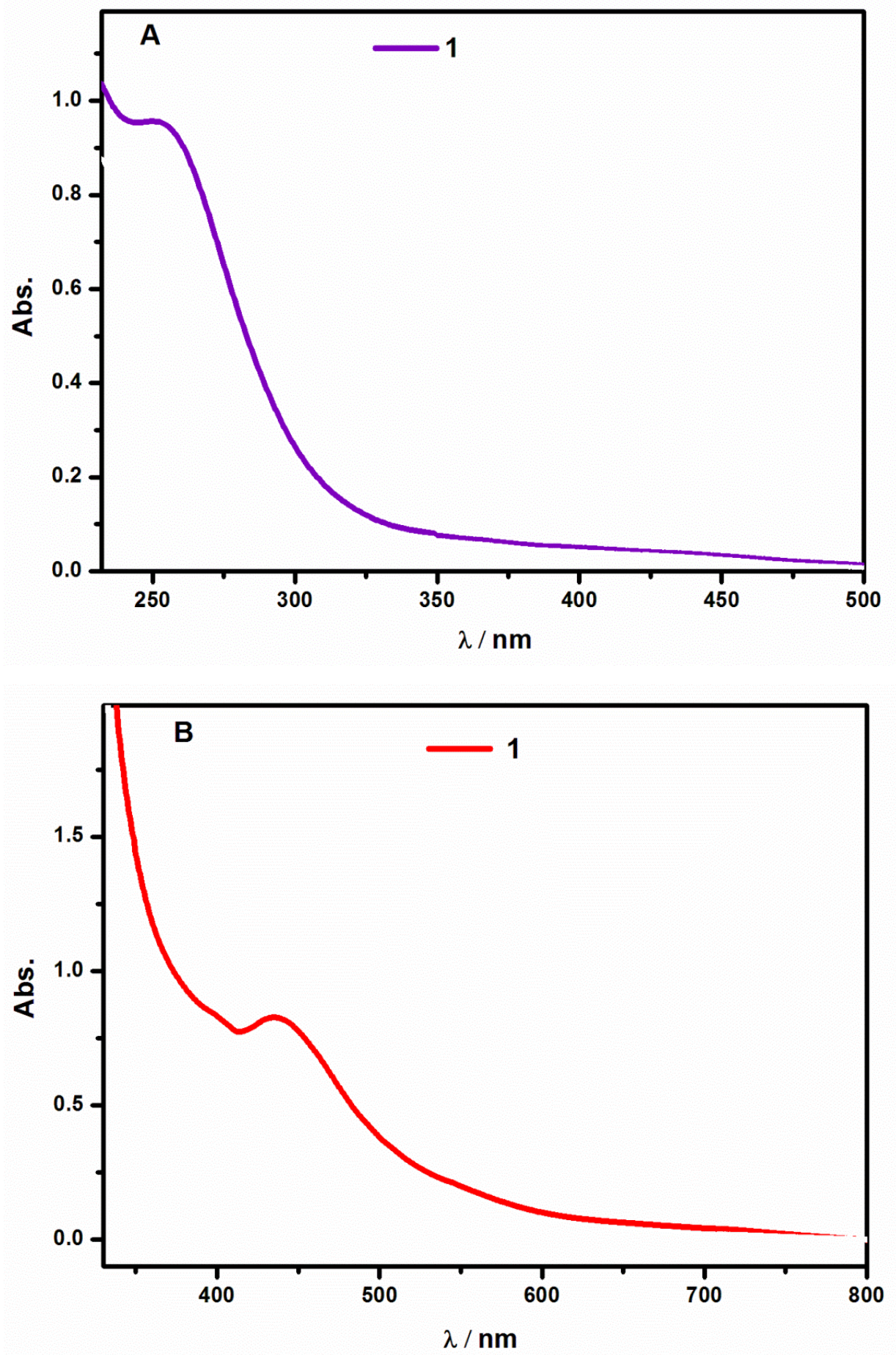

Figure S7. Absorption spectra of 1 recorded in a pH $7(1 \mathrm{M} \mathrm{Li} \mathrm{CH} 3 \mathrm{COO}+\mathrm{CH} 3 \mathrm{COOH})$ medium with a $1 \mathrm{~cm}$ optical path quartz cuvette. (A) Spectrum of the $\mathrm{W}$ centers; the POM concentration was $6.7 \mu \mathrm{M}$. (B) Spectrum of the Mn centers; the POM concentration was $400 \mu \mathrm{M}$. 


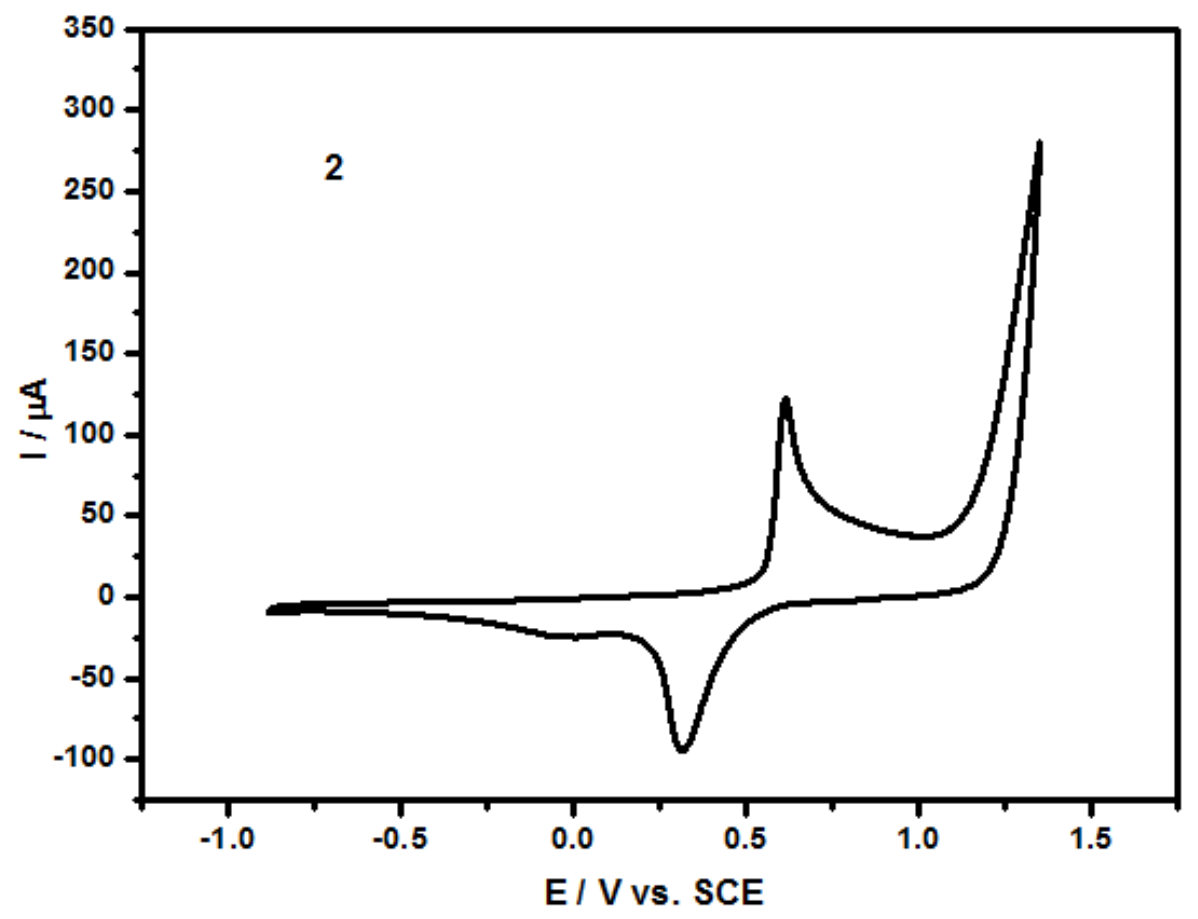

Figure S8. Redox activity of the $\mathrm{Mn}^{3+}$ and $\mathrm{Mn}^{4+}$ centers of $50 \mu \mathrm{M} 2$ in a $\mathrm{pH} 7$ medium (1M $\mathrm{LiCH}_{3} \mathrm{COO} / \mathrm{CH}_{3} \mathrm{COOH}$ ). The scan rate was $100 \mathrm{mV} \mathrm{s}^{-1}$, and the reference electrode was a saturated calomel electrode (SCE). 